\title{
Characterization of the mitochondrial genome of Analcellicampa xanthosoma gen. et sp. nov. (Hymenoptera: Tenthredinidae)
}

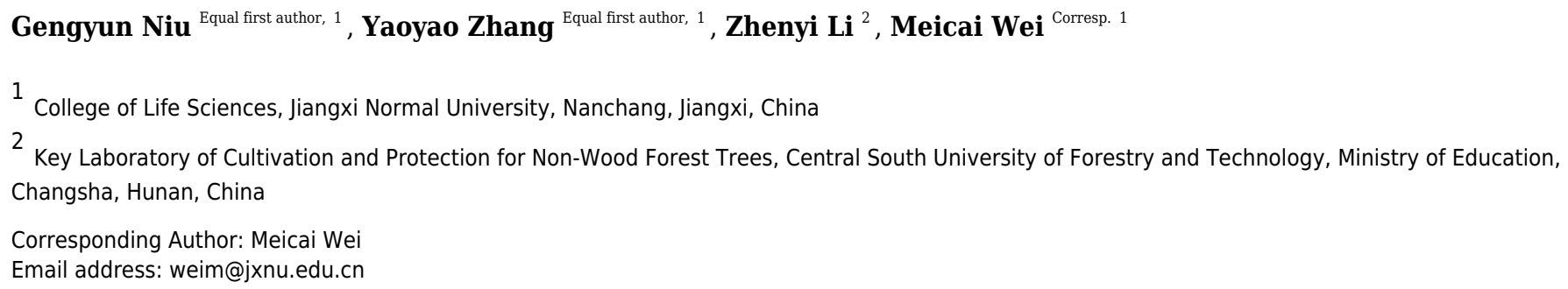

A new genus with a new species of the tribe Hoplocampini of Hoplocampinae was described from China: Analcellicampa xanthosoma Wei \& Niu, gen. et sp. nov. Hoplocampa danfengensis G. Xiao, 1994 was designated as the type species of the new genus. The characters of Analcellicampa danfengensis (G. Xiao) comb. nov. were briefly discussed. A key to the tribes and known genera of Hoplocampinae was provided. The nearly complete mitochondrial genome of $A$. xanthosoma was characterized as having a length of 15512 bp and containing 37 genes (22 tRNAs, 13 protein-coding genes (PCGs), and 2 rRNAs). The gene order of this new specimen was the same as that in the inferred insect ancestral mitochondrial genome. All PCGs were initiated by ATN codons and ended with TAA or T stop codons. All tRNAs had a typical cloverleaf secondary structure, except for trnS1. Remarkably, the helices H991 of rrnS and H47 of $r r n L$ were redundant, while helix $\mathrm{H} 563$ of $r r n L$ was highly conserved. A phylogeny based on previously reported symphytan mitochondrial genomes showed that $A$. xanthosoma is a sister group to Monocellicampa pruni, with high support values. We suggest that $A$. xanthosoma as well as M. pruni belongs to the tribe Hoplocampini of Hoplocampinae. 
1 Characterization of the mitochondrial genome of

2 Analcellicampa xanthosoma gen. et sp. nov.

3 (Hymenoptera: Tenthredinidae)

4

5 Gengyun $\mathrm{Niu}^{1}{ }^{*}$, Yaoyao Zhang ${ }^{*}$, Zhenyi $\mathrm{Li}^{2}$ and Meicai Wei ${ }^{1}$

6

$7 \quad{ }^{1}$ College of Life Sciences, Jiangxi Normal University, Nanchang, Jiangxi, China

$8{ }^{2}$ Key Laboratory of Cultivation and Protection for Non-Wood Forest Trees, Central South

9 University of Forestry and Technology, Ministry of Education, Changsha, Hunan, China

$10 *$ These authors contributed equally to this work.

12 Corresponding Author:

13 Meicai Wei ${ }^{1}$

1499 Ziyang Road, Nanchang, Jiangxi 330022, China

15 Email address: weim@jxnu.edu.cn 


\section{ABSTRACT}

43 A new genus with a new species of the tribe Hoplocampini of Hoplocampinae was described 44 from China: Analcellicampa xanthosoma Wei \& Niu, gen. et sp. nov. Hoplocampa danfengensis 45 G. Xiao, 1994 was designated as the type species of the new genus. The characters of 46 Analcellicampa danfengensis (G. Xiao) comb. nov. were briefly discussed. A key to the tribes 47 and known genera of Hoplocampinae was provided. The nearly complete mitochondrial genome 48 of A. xanthosoma was characterized as having a length of $15512 \mathrm{bp}$ and containing 37 genes (22 49 tRNAs, 13 protein-coding genes (PCGs), and 2 rRNAs). The gene order of this new specimen 50 was the same as that in the inferred insect ancestral mitochondrial genome. All PCGs were 51 initiated by ATN codons and ended with TAA or T stop codons. All tRNAs had a typical 52 cloverleaf secondary structure, except for trnS1. Remarkably, the helices H991 of $r r n S$ and H47 53

54

55

56

57

58

59

60

61

62

63

64

65

66

67

68

69

70

71

72

73

74

75

76

77

78

79

80

of $r r n L$ were redundant, while helix $\mathrm{H} 563$ of $r r n L$ was highly conserved. A phylogeny based on previously reported symphytan mitochondrial genomes showed that $A$. xanthosoma is a sister group to Monocellicampa pruni, with high support values. We suggest that A. xanthosoma as well as M. pruni belongs to the tribe Hoplocampini of Hoplocampinae.

\section{INTRODUCTION}

The Nematinae s. lat. (sensu Prous et al., 2014) is the second-largest subfamily within the Tenthredinidae and includes approximately 1260 known species (Taeger et al., 2010; Wei \& Niu, 2011; Li \& Wei, 2012; Wei \& Xia, 2012; Liu, Niu et al., 2017; Liu, Liu et al., 2017; Liu, Li et al., 2018a, b).

The systematic arrangement of the genera of Nematinae s. lat. has not yet reached consensus, and approximately ten different systems have been proposed since Ashmead (1898a). Before Ashmead (1898a), the taxon was regarded as a subfamily of Tenthredinidae by Kirby (1882), Cameron (1882) and Dalla Torre (1894). Ashmead (1898a) first established a family for Nematinae auct. except Hoplocampinae, which he placed into Selandriidae (Ashmead, 1898b). Ashmead's opinion was overlooked by many Symphyta researchers, who treated Nematinae s. lat. as a normal subfamily of Tenthredinidae (MacGillivray, 1906; Benson, 1938; Takeuchi, 1952; Benson, 1958; Malaise, 1963; Zhelochovtsev, 1988; Taeger et al., 2010; Prous et al., 2014). Seldom has the taxon been treated as a tribe of Tenthredininae (Enslin, 1918) or even a subtribe of Tenthredinini (Konow, 1905). A few researchers separated Nematinae s. lat. into Nematinae s. str. and Hoplocampinae (Rohwer, 1911), Susaninae and Nematinae (Ross, 1951; Maxwell, 1955; Smith \& Burks, 1979; Abe \& Smith, 1991), or Cladiinae and Nematinae (Ross, 1937) or regarded it as Nematidae, a family of Tenthredinoidea s. str., with 3 subfamilies: Hoplocampinae, Susaninae and Nematinae s. str. (Wei \& Nie, 1998).

Nyman et al. (2006) analyzed the internal phylogeny of Nematinae s. lat. based on the COI gene and the nuclear elongation factor- $1 \alpha$ gene. The branches (Craterocercus + (Susana, Hoplocampa) ) and (Cladius + (Priophorus, Trichiocampus $)$ ) were the two most basal paraphyletic clades. 
81 Based on a molecular phylogenetic study, Prous et al. (2014) proposed the latest system for 82 Nematinae s. lat. The authors regarded (((Susana, Hoplocampa) Cladius) + Craterocercus + 83 Monocellicampa) as a middle monophyletic clade of Nematinae s. lat. based on Bayesian 84 analysis or ((Susana, Hoplocampa) (Moricella, Cladius)) as a basal monophyletic clade of 85 Nematinae s. lat. based on maximum likelihood (ML) analysis. The branch of (Susana + 86 Hoplocampa + Cladius) of Nematinae s. lat. is most likely a monophyletic group, although the 87 systematic position and the members of the branch are uncertain: the position of 88 Monocellicampa, Craterocercus and Moricella is questionable. Importantly, the cladograms of 89 Nematinae s. lat. in Prous et al. (2014) were reconstructed based only on 400-bp sequences of 90 the barcode region.

91 Based on a comparison of external morphology, Analcellicampa Wei \& Niu gen. nov. and 92 Monocellicampa Wei are undoubtedly members of Hoplocampini, and they are quite closely 93 related to Hoplocampa, as shown by the following characteristics: head strongly flattened; mandibles short and hardly bent, symmetrically tridentate; epicnemium of the mesepisternum flat, with the epicnemial suture fine and vestigial; antenna short and filiform with two basal antennomeres much longer than broad; anal cell in the forewing with a long constricted petiole

97

98

99

100

101

102

103

104

105

106

107

108

109

110

111

112

113

114

115

116

117

118

119

120

121 near the basal 0.4 , vein $2 \mathrm{r}$ present, $1 \mathrm{~m}$-cu meeting cell $1 \mathrm{Rs}$ and $2 \mathrm{~m}$-cu meeting cell $2 \mathrm{Rs}$; and radix of the lancet and lance quite short. Analcellicampa and Monocellicampa are probably sister groups within Hoplocampini, as the two genera share a peculiar synapomorphic character with the Nematidae of Wei \& Nie (1998): cell M in the hind wing open. Caulocampus Rohwer, 1912 and Armenocampus Zinovjev, 2000 are two closely related genera and probably also members of Hoplocampini. In addition, Anhoplocampini, including Anhoplocampa Wei, 1998 and Zhuangzhoua Liu et al., 2017, is regarded as a tribe of Hoplocampinae and related to Cladiini (Liu et al., 2017).

A broadened Hoplocampinae subfamily based on Wei (1998), Wei \& Nie (1998) and Prous et al. (2014) is followed tentatively in this paper. The tribes of the subfamily are rearranged. However, there is a strong possibility that Susanini, Hoplocampini, Anhoplocampini and Cladiini are basal paraphyletic groups of Nematinae s. lat. (= Nematidae sensu Wei \& Nie, 1998).

Here, to confirm the sister group relationship between Monocellicampa and Analcellicampa and to help clarify the systematic position of Analcellicampa within Tenthredinidae, the mitochondrial genome of Analcellicampa xanthosoma was sequenced and phylogenetically analyzed, and the new genus and new species were described. For comparison and identification of the members of Hoplocampinae, a key to the tribes and known genera of Hoplocampinae was also provided.

\section{MATERIALS \& METHODS}

\section{Description of the new species}

Insect specimens were examined using a Leica S8APO dissecting microscope. Detailed images of adults were taken with a Leica Z16 APO/DFC550 and were then montaged using Helicon Focus (Helicon Soft). Montaged images were further processed using Adobe Photoshop CS 6.0.

Peer) reviewing PDF | (2018:09:31616:3:1:NEW 2 Mar 2019) 
122 The terminology used for sawfly genitalia follows Ross (1945), whereas the terminology for

123

124

125

126

127

128

129

130

131

132

133

134

135

136

137

138

139

140

141

142

143

144

145

146

147

148

149

150

151

152

153

154

155

156

157

158

159

160

161

162

general morphology follows Viitasaari (2002). Abbreviations are as follows: OOL $=$ distance between the eye and outer edge of lateral ocelli; POL $=$ distance between the mesal edges of lateral ocelli; and OCL $=$ distance between the lateral ocellus and the occipital carina or hind margin of the head.

The holotype and all paratypes of the new species were deposited in the Asian Sawfly Collection (ASC), Nanchang, China.

The electronic version of this article in portable document format (PDF) will represent a published work according to the International Commission on Zoological Nomenclature (ICZN), and hence, the new names contained in the electronic version are effectively published under the code from the electronic edition alone. This published work and the nomenclatural acts it contains have been registered in ZooBank, the online registration system for the ICZN. The ZooBank Life Science Identifiers (LSIDs) and associated information can be viewed through any standard web browser by appending the LSID to the prefix http://zoobank.org/. The LSID for this publication is urn: 1sid: zoobank. org: pub: 8093814F-7A3A-460B-A590-4EF928A280E1. The online version of this work is archived and available from the following digital repositories: PeerJ, PubMed Central and CLOCKSS.

\section{DNA library construction and sequencing}

Total DNA was extracted from $A$. xanthosoma using an E.Z.N.A. ${ }^{\circledR}$ Tissue DNA Kit (Omega, Norcross, GA) following the manufacturer's instructions and stored at $-20^{\circ} \mathrm{C}$. Sequencing libraries with approximately 400-bp insertions were constructed using a NEXTflex ${ }^{\mathrm{TM}}$ Rapid DNA-Seq Kit (Illumina, San Diego, CA) according to the manufacturer's protocol. Each library was sequenced on an Illumina HiSeq X Ten to generate 150-bp paired-end reads.

\section{Mitogenome assembly}

Next-generation sequencing and bioinformatic analyses were performed by Shanghai Majorbio Bio-pharm Technology Co., Ltd. Reconstruction of the mitochondrial genome from Illumina reads was carried out using three different approaches to ensure the accuracy of the assemblies: SOAPdenovo v2.0 (Luo et al.,2012), MITObim v1.8 (Hahn, Bachmann \& Chevreux, 2013) and NOVOPlasty v2.7.1 (Dierckxsens, Mardulyn \& Smits, 2017). The assembled mitochondrial fragments were identified by BlastX using Asiemphytus rufocephalus (KR703582) mitochondrial genes as queries.

\section{Mitogenome annotation and secondary structure prediction}

All RNA genes were identified by employing the online MITOS tool (http://mitos.bioinf.unileipzig.de/index.py) (Bernt et al., 2013) with the invertebrate mitochondrial genetic code. The initiation and termination codons of protein-coding genes (PCGs) were determined by Geneious v8.0.5 (http://www.geneious.com) using reference sequences from other symphytan species with subsequent manual adjustment. The $\mathrm{A}+\mathrm{T}$ content of nucleotide sequences and relative synonymous codon usage (RSCU) were calculated using MEGA v7.0 (Kumar, Stecher \& 
163 Tamura, 2016). Strand asymmetry was calculated using the formulas (Perna and Kocher, 1995) 164 GC-skew $=(\mathrm{G}-\mathrm{C}) /(\mathrm{G}+\mathrm{C})$ and AT-skew $=(\mathrm{A}-\mathrm{T}) /(\mathrm{A}+\mathrm{T})$ for the strand encoding the 165 majority of the PCGs.

166 The secondary structures of $r r n S$ and $r r n L$ were partitioned into four areas and six areas, 167 respectively. Secondary structures of rRNAs were inferred using alignment to models predicted 168 for Trichiosoma anthracinum and Labriocimbex sinicus (Yan et al., in press). First, the primary 169 sequence and the secondary structure of these two species were aligned in MARNA (Siebert \& 170 Backofen, 2005) to identify a consensus sequence as well as a consensus structure in the output 171 files. Second, the secondary structures of $r r n S$ and $r r n L$ in A. xanthosoma were predicted by 172 specific structural models in SSU-ALIGN (Nawrocki, 2009). Finally, the structures were 173 artificially transformed into their relative secondary structures with minor changes.

174 The predicted secondary structures of RNAs were drawn using VARNA v3-93 (Darty, Denise \& 175 Ponty, 2009) and RnaViz 2.0.3 (De Rijk, Wuyts \& De Wachter, 2003). Helix numbering follows that of Apis mellifera (Gillespie et al., 2006), with minor modifications.

\section{RESULTS AND DISCUSSION}

201

202

\section{Phylogenetic analysis}

We used the ML and Bayesian inference (BI) methods to construct phylogenetic trees of selected species using 13 PCGs and two rRNAs (Table 1). The mitochondrial genome sequences of the selected species were downloaded from GenBank. Thirteen PCGs were aligned individually by MUSCLE in MEGA v7.0, and two rRNAs were aligned by MAFFT (https://www.ebi.ac.uk/Tools/msa/mafft/) (Katoh \& Standley, 2013). Then, the aligned nucleotide sequences were concatenated with SequenceMatrix v1.7.8 (Vaidya, Lohman \& Meier, 2011) and partitioned into several data blocks.

The partitioned data block file was used to infer both partitioning schemes and substitution models in PartitionFinder v1.1.1 (Lanfear et al., 2012) with "unlinked" branch lengths under the "greedy" search algorithm. The standard partitioning schemes "bic" and "aicc" were selected for $\mathrm{BI}$ and ML analyses, respectively. BI analyses were conducted with the GTR $+\mathrm{I}+\mathrm{G}$ model and $\mathrm{HKY}+\mathrm{G}$ model using MrBayes v3.2.2 (Ronquist et al., 2012). Four simultaneous Markov chains (three cold, one heated) were run for two million generations in two independent runs, with sampling every 1000 generations and $25 \%$ of the first generations discarded as burn-in.

ML analyses were conducted with the GTR $+\mathrm{I}+\mathrm{G}, \mathrm{GTR}+\mathrm{G}$ and $\mathrm{HKY}+\mathrm{G}$ models.. With the bestfit model of nucleotide substitution, phylogenetic construction based on ML was performed on the IQ-TREE web server (http://iqtree.cibiv.univie.ac.at/). The previous data block file as well as the original parameters was also used. In addition, 0.1 was employed as the disturbance intensity, and 1000, as the IQ-TREE stopping rule.

All related files have been uploaded to figshare (http://figshare.com/s/5d9c3789708b3ebdbe2c).

\section{Description}


203

204

205

206

207

208

209

210

211

212

213

214

215

216

217

218

219

220

221

222

223

224

225

226

227

228

229

230

231

232

233

234

235

236

237

238

239

240

241

242

\section{Analcellicampa Wei \& Niu, gen. nov.}

urn: 1sid: zoobank. org: act: FFD0BF94-EF5B-4BE1-8943-72A766426E9A

Type species: Hoplocampa danfengensis G. Xiao, 1994.

Description. Body small, not slender (Figure 1). Head strongly compressed in lateral view (Figure 2c); clypeus broad, flat, anterior margin shallowly incised (Figures 2b, 3c); eyes large, inner margins convergent downwards, shortest distance between eyes longer than longest axis of eye (Figures 2b, 3c); malar space as long as or shorter than diameter of median ocellus (Figures $2 \mathrm{~b}, 3 \mathrm{c}$ ); mandibles short, evenly tapering toward apex, subsymmetrically tridentate, middle tooth sharp, lowest tooth obtuse (Figures $4 \mathrm{~g}, 4 \mathrm{~h}$ ); maxillary palp with 6 palpomeres, palpomere 3 not enlarged (Figure 4c); labial palp with 4 palpomeres, palpomere 3 roundish (Figure 4d); middle fovea absent, lateral fovea small but distinct (Figure 2b); hind orbit round, postorbital groove and occipital carina absent; frons weakly elevated, frontal wall indistinct; ocellar triangle very low; postocellar area very short and broad, approximately 3-4.5 times as broad as long; in dorsal view, temple very short and strongly narrowed behind eyes (Figures 2a, 3f); antenna short and slender, not longer than head and thorax together, much shorter than vein $\mathrm{C}$ of forewing, scape and pedicel much longer than broad, antennomere 3 clearly longer than antennomere 4 , antennomeres 5-8 each less than 3 times as long as broad (Figures 21, 4i); mesepisternum roundly and weakly elevated, epicnemium flat, largely glabrous, epicnemial suture fine but distinct, not furrow-like (Figure 2f); inner apical spur of fore tibia not bifurcate, with a distinct membranous lobe reaching halfway to apex (Figure 4e); hind tibia as long as or slightly longer than hind tarsus, inner apical spur of hind tibia shorter than apical breadth of tibia; metabasitarsus as long as following 3 tarsomeres together; tarsal pulvilli distinct (Figure 4j); claw small, roundly bent, basal lobe and inner tooth absent (Figures 2j, 4f). Forewing (Figure $4 \mathrm{a})$ : veins $1 \mathrm{M}$ and $1 \mathrm{~m}$-cu strongly convergent toward pterostigma, vein $\mathrm{R}+\mathrm{M}$ not shorter than cua, first abscissa of vein Rs entire but weak, cell 1Rs shorter than cell 2Rs, vein $2 \mathrm{r}$ present, $2 \mathrm{r}$ and $2 \mathrm{~m}$-cu meeting cell $2 \mathrm{Rs}$, vein cu-a meeting cell $1 \mathrm{M}$ near middle, anal cell broadly constricted at approximately basal third with a long middle petiole, basal anal cell closed. Hindwing (Figure 4b): cells R1 and Rs closed, cells M and A open, vein 2A very short and approximately 1.5-3 times length of vein cu-a; cercus slender, approximately 3-10 times as long as broad (Figures $2 \mathrm{~h}$, 3e); ovipositor sheath shorter or longer than hind femur, apical sheath approximately as long as or longer than basal sheath, tapering toward apex (Figures 2g, 3e); lancet weakly sclerotized, ctenidium and spiculella absent, serrulae oblique with fine subbasal teeth, radix less than 0.3 times total length of lancet (Figures $2 \mathrm{k}, 3 \mathrm{~g}$ ); gonocardo quite narrow at middle and distinctly broadened laterally, middle breadth approximately 2.5 times breadth of thinnest lateral arm (Figure 3i); penis valve with a small apical lobe, without stout valvispina, surface of valviceps with many small teeth (Figure 3k); harpe longer than broad (Figure 3i).

Etymology. The generic name, Analcellicampa, is composed of Anal- and -cellicampa, with the former referring to the open hind anal cell of the new genus and the latter referring to a part of the name of Monocellicampa, the nearest relative of Analcellicampa gen. nov.

Distribution. China. 
243 Host plant: Cerasus spp. of Rosaceae. Larvae are borers of the fruits of Cerasus spp.

244 Remarks. This new genus is a member of Hoplocampinae (Wei, 1998; Wei \& Nie, 1998) and 245 allied to Monocellicampa Wei, 1999 but differs from it by the following: the anal cell of hind 246 wing broadly opened at apex, vein $2 \mathrm{~A}$ very short; epicnemium large with a distinct epicnemial 247 suture; head strongly compressed in lateral view; the inner tibial spur of foreleg simple with a 248 membranous lobe far from apex; the gonocardo quite narrow; the valviceps of penis valve 249 without a stout valvispina but with many small surface teeth; larvae feed on Cerasus spp. In 250 Monocellicampa, the anal cell of hind wing closed, vein 2A as long as 1A; epicnemium vestigial 251 with epicnemial suture indistinct; head weakly compressed in lateral view; the inner tibial spur of 252 foreleg bifurcate at apex; the gonocardo broad; the valviceps of penis valve with a stout 253 254 255 256 257 258 259 260 261 262 valvispina and without small surface teeth; larvae feed on Prunus spp.

\section{Analcellicampa xanthosoma Wei \& Niu, sp. nov. (Figures 1-2)} urn: 1sid: zoobank. org: act: 4EB9F310-6479-4363-A481-81ECF9EF18B6

Female. Body length $5 \mathrm{~mm}$ (Figure 1). Body yellow-brown; head black, clypeus and mandibles largely black, labrum and palps pale brown (Figure 2b), antennal flagellum dark brown to blackbrown (Figure 21); anterior 0.3 of propleuron black-brown; center of mesoscutal middle lobe, top of mesoscutal lateral lobe, posterior of mesoscutellum, metascutellum, narrow inner margins of first terga and center of abdominal tergites $2-3$ dark brown (Figure 1). Body hairs brown. Wings hyaline, pterostigma and veins pale brown.

Clypeus with large and very shallow punctures, shiny (Figure 2b); dorsum of head finely punctured with narrow but recognizable interspaces except frons and anterior of temple densely punctured, interspaces linear (Figure 2a); mesoscutal middle lobe and lateral lobes finely punctured with linear interspaces, most of mesoscutellum with somewhat larger punctures, interspaces distinct and shiny; parapsis largely and lateral corners of mesoscutellum highly smooth, strongly shiny; mesoscutellar appendage and metascutellum distinctly punctured (Figure 2d), metapostnotum coriaceous; mesepisternum sparsely and finely punctured, interspaces broad and smooth, shiny (Figure 2f); metapleuron finely punctured with weak microsculptures, weakly shiny; abdominal tergum 1 distinctly microsculptured (Figure 2e), other tergites weakly coriaceous, shiny.

Hairs on dorsum of head and thorax very short, shorter than 0.2 times the diameter of the lateral ocellus. Clypeus triangularly incised to a depth of approximately 0.3 times the length of the clypeus, malar space 0.6 times the diameter of the median ocellus; middle fovea absent, lateral fovea small but distinct; area in front of ocellar triangle flat and broad (Figure 2b), distance between lower corner of eyes 1.3 times the longest axis of the eye; frons hardly elevated, frontal wall indistinct, frontal basin absent; anterocellar furrow transverse, distinct, interocellar furrow fovea-like, postocellar furrow short and almost in line with interocellar fovea (Figure 2a); OOL:POL:OCL $=9: 8: 6$; postocellar area approximately 3 times as broad as long, posterior slightly elevated (Figure 2a); in dorsal view, head strongly narrowed behind eyes, temple approximately half the length of the eye, lateral view as in Figure 2c; antenna as long as head 
283

284

285

286

287

288

289

290

291

292

293

294

295

296

297

298

299

300

301

302

303

304

305

306

307

308

309

310

311

312

313

314

315

316

317

318

319

320

321

322

and thorax together, clearly shorter than vein $\mathrm{C}$ of forewing, antennomere 31.35 times as long as antennomere 4, antennomere 82.2 times as long as broad. Mesoscutellum and appendage as Figure 2d; mesepisternum flat (Figure 2f). Hind tibia slightly longer than tarsus, metabasitarsus as long as following 3 tarsomeres together; claw simple (Figure 2j). Abdominal tergum 1 as in Figure 2e; ovipositor sheath as long as middle tarsus and 0.8 times as long as hind tibia, apical sheath 1.6 times as long as basal sheath, apex subtriangular in lateral view (Figure $2 \mathrm{~g}$ ); cercus very long and slender, length approximately 10 times its middle breadth and reaching apex of sheath in dorsal view (Figure 2h). Lancet with 14 oblique serrulae and 10 distinct annular sutures, apical 6 annuli without annular suture (Figure 2k); subapical serrulae each with 7-9 small distal subbasal teeth, proximal subbasal tooth absent (Figure 2i).

Male. Unknown.

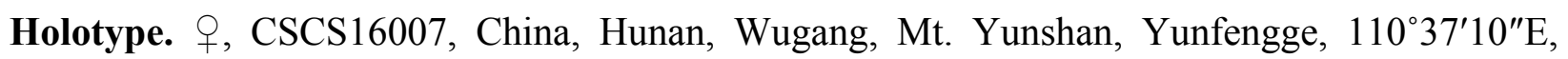
$26^{\circ} 38^{\prime} 59^{\prime \prime} \mathrm{N}$, alt. 1170 m, March 27, 2016, Meicai Wei and Gengyun Niu leg.

Paratypes. 1 q, data same as the holotype; 1 q, CSCS16007, China, Hunan, Wugang, Mt. Yunshan, Yunfengge, $110^{\circ} 37^{\prime} 10^{\prime \prime} \mathrm{E}, 26^{\circ} 38^{\prime} 59^{\prime \prime} \mathrm{N}$, alt. $1170 \mathrm{~m}$, March 27, 2016, Meicai Wei and Gengyun Niu leg, CSCS-Hym-MC0017; 1 q, CSCS16007, China, Hunan, Wugang, Mt. Yunshan, Yunfengge, $110^{\circ} 37^{\prime} 10^{\prime \prime} \mathrm{E}, 26^{\circ} 38^{\prime} 59^{\prime \prime} \mathrm{N}$, alt. $1170 \mathrm{~m}$, March 27, 2016, Meicai Wei and Gengyun Niu leg, CSCS-Hym-M02046; 1 q, CSCS12001, China, Hunan, Wugang, Mt. Yunshan, Dianshita, 110³7.299'E, 26³8.630'N, alt. 1380 m, April 9, 2012, Zejian Li, Zaiyang Pan leg; 4 우, CSCS12001, China, Hunan, Wugang, Mt. Yunshan, Dianshita, 110³7.299'E, $26^{\circ} 38.630^{\prime} \mathrm{N}$, alt. $1380 \mathrm{~m}$, April 9, 2012, Zejian Li, Zaiyang Pan leg, CSCS-Hym-M2018, M2019, M2020, M2043.

Etymology. The specific epithet refers to the body color.

Distribution. China (Hunan).

Remarks. This new species differs from the type species of the genus by the following: thorax, abdomen and legs almost entirely yellow-brown, wings hyaline, the pterostigma and veins pale brown, postocellar area approximately 3 times as broad as long, very long and slender cerci approximately 10 times as long as broad, the ovipositor apical sheath 1.6 times as long as basal sheath and the basal 10 annular sutures of lancet distinct. In Analcellicampa danfengensis, the body and legs entirely black in females, wings infuscate toward the apex, pterostigma and veins black-brown, postocellar area approximately 4-4.5 times as broad as long, cerci approximately 5 times as long as broad, the ovipositor apical sheath 1.2 times as long as basal sheath and all annular sutures of lancet indistinct.

\section{Analcellicampa danfengensis (Xiao, 1994) comb. nov. (Figures 3-4)}

\section{Hoplocampa danfengensis G. Xiao, 1994: 442-444.}

Notes. Body length 4-4.5 mm. Black (Figures 3a, 3b); antenna black-brown (Figure 4i), tibiae and base of basitarsi pale brown to dark brown; subgenital plate of male yellow-brown (Figure $3 b$ ). Wings infuscate toward apex, vein $\mathrm{C}$ and stigma dark brown to black-brown (Figures 4a, 4b). Anterior incision of clypeus roundish, shallow; interocellar and postocellar furrows fine and 
323 shallow; posterior of postocellar area weakly elevated, approximately 4-4.5 times as broad as 324 long (Figure 3f). Body finely and densely punctured, abdomen mixed with microsculptures. 325 Antennomere 31.3 times as long as antennomere 4 (Figure 4i). Epicnemial suture fine (Figure 326 3d). Cercus slender, approximately 5 times as long as broad (Figure 3e). Ovipositor apical sheath 3271.2 times as long as basal sheath (Figure 3e); lancet with 17-19 serrulae, annular sutures 328 indistinct (Figure 3g), middle serrulae distinctly oblique, with indistinct fine subbasal teeth 329 (Figure 3h). Gonoforcep as shown in Figure 3i, harpe longer than broad; penis valve as shown in 330 Figure 3j, apical lobe short and small, valviceps with dense small spines (Figure 3k).

331 Distribution. China (Gansu, Shaanxi, Hunan, Zhejiang, and Sichuan).

332 Host plant: Cerasus pseudocerasus (Lindl.).

333 Sun \& Jiang, (1994) reported on the biology of this species but under the name Fenusa sp. The 334 name was defined by Gangrou Xiao in 1994. Later in the same year, Xiao described the species 335

336

337

338

339

340

341

342 as new to science with the name Hoplocampa danfengensis.

\section{A revised key to the tribes and known genera of Hoplocampinae}

1 Antennal flagellum shorter than 2 times head breadth, middle flagellomeres less than 3 times as long as broad; second antennomere clearly longer than broad; forewing with vein $2 \mathrm{r}$ usually present (except Caulocampus); lancet narrow and long, not distinctly sclerotized, without ctenidium; larvae feeding internally on some species of Angiospermae. Hoplocampini...2

343

344

345

346

347

348

349

350

351

352

353

354

355

356

357

358

359

360

361

362

- Length of antennal flagellum more than 2 times head breadth, middle flagellomeres clearly more than 3 times as long as broad or distinctly branched; forewing with vein $2 \mathrm{r}$ absent; lancet usually strongly sclerotized with distinct ctenidia; larvae feeding externally on some species of Gymnospermae or Angiospermae...6

2 Forewing with vein $2 \mathrm{r}$ absent; larvae boring into leaf petioles or unknown...3

- Forewing with $2 \mathrm{r}$ present; larvae tunneling into and feeding within fruits... 4

3 Claw short and strongly bent at middle with a large inner tooth; apex of hind anal cell truncate, petiole of anal cell extending from dorsal margin of cell A; larvae boring into leaf petioles. North America...Caulocampus Rohwer, 1912

- Claw slender and not strongly bent at middle, without inner tooth; apex of hind anal cell acute at apex and petiole of anal cell extending from apex of cell A; larvae unknown...Armenocampus Zinovjev, 2000

4 Cell $\mathrm{M}$ in hind wing closed; claw with minute inner tooth; penis valve simple or with a long apical filament, without many small spines or a large valvispina, usually with some warts; lancet usually with spiculella, and serrula with several large teeth...Hoplocampa Hartig, 1837

- Cell M in hind wing open; claw without inner tooth; penis valve with a distinct subapical valvispina or simple with many small spines; lancet without spiculella, serrula with several minute teeth...5

5 Hind anal cell broadly open with a short $2 \mathrm{~A}$ vein; penis valve simple without a subapical valvispina but with many small spines; gonocardo quite narrow...Analcellicampa Wei \& Niu, gen. nov.

Peer) reviewing PDF | (2018:09:31616:3:1:NEW 2 Mar 2019) 
363

364

365

366

367

368

369

370

371

372

373

374

375

376

377

378

379

380

381

382

383

384

385

386

387

388

389

390

391

392

393

394

395

396

397

398

399

400

401

402

403

- Hind anal cell closed and vein $2 \mathrm{~A}$ as long as $1 \mathrm{~A}$; penis valve with a distinct subapical valvispina, without many small spines; gonocardo very broad...Monocellicampa Wei, 1998

6 Forewing with vein $2 \mathrm{r}$ usually present; epicnemium of mesepisternum absent or very narrow and flat; petiole of hind anal cell about as long as vein cu-a; pseudoceps of penis valve with a stout spine, paravalva simple; larvae feeding on leaves of Cupressaceae, Gymnospermae. North America. Susanini...Susana Rohwer \& Middleton, 1932

- Forewing with vein $2 \mathrm{r}$ always absent; epicnemium broad and flat or narrow and strongly elevated; petiole of hind anal cell much longer than vein cu-a or shorter than cu-a; pseudoceps of penis valve simple, without a stout spine, paravalva usually with a stout spine (valvispina); larvae feeding on leaves of several families of Angiospermae...7

7 Mesepisternum with a narrow and strongly elevated epicnemium; forewing with vein $R+M$ clearly longer than vein cu-a, first abscissa of vein Rs complete; petiole of hind anal cell shorter than vein cu-a; left mandible in outer view slender in apical 0.7 and strongly enlarged in basal 0.3. Anhoplocampini...8

- Mesepisternum with a broad and flat epicnemium; forewing with vein $\mathrm{R}+\mathrm{M}$ clearly shorter than vein cu-a, first abscissa of vein Rs absent; petiole of hind anal cell much longer than vein cu-a; left mandible in outer view evenly enlarged toward base. Holarctic. Cladiini...Cladius Illiger, 1807

8 Antenna simple, filiform; forewing with vein $\mathrm{R}$ shorter than half length of vein Sc; middle petiole of anal cell in forewing approximately as long as vein cu-a; forewing with a distinct transversal macula. China... Anhoplocampa Wei, 1998

- Antennal flagellomeres 3-8 with distinct apical process or long lobe; forewing with vein $\mathrm{R}$ clearly longer than vein Sc; middle petiole of anal cell in forewing less than half the length of vein cu-a; forewing without a transversal macula. China... Zhuangzhoua Wei et al. 2018

\section{Architecture and nucleotide composition of the $A$. xanthosoma mitochondrial genome}

The nearly complete mitochondrial genome of $A$. xanthosoma had a length of 15512 bp and contained 37 genes (22 tRNAs, 13 PCGs, and two rRNAs). The mitogenome sequence was deposited in GenBank under the accession number MH992752. The 37 genes, except for four PCGs (ND1, ND4, ND4L and ND5), two rRNAs and eight tRNAs, were located on the J-strand (Table 2).

The gene order was the same as the ancestral order except for the IQM cluster (Figure 5). Accordingly, the causes of mitochondrial genome rearrangements in insects are likely multifactorial, and much additional research is required (Cameron, 2014). In the A. xanthosoma mitochondrial genome, a total of 239 bp of intergenic spacer sequences were found in 18 locations (except for the A+T-rich region) and varied in size from one to $29 \mathrm{bp}$. Additionally, a total of 11 overlapping nucleotides were scattered in five locations, with the longest (ATGATAA) located between ATP 8 and ATP6.

\section{Protein-coding genes and codon usage}

All PCGs were initiated with ATN as the start codon and ended with a complete termination

Peer) reviewing PDF | (2018:09:31616:3:1:NEW 2 Mar 2019) 
404 codon except for the ND3 and ND4 genes, which terminated with an incomplete stop codon T 405 (Table 2).

406 The A + T content, AT-skew and GC-skew are three parameters usually used in investigations of 407 nucleotide composition in mitochondrial genomes (Hassanin, Léger \& Deutsch, 2005; Perna \& 408 Kocher, 1995). The A. xanthosoma mitochondrial genome was biased toward A and T, with an $40980.0 \% \mathrm{~A}+\mathrm{T}$ content (Table 3 ). The AT- and GC-skews were found to be mostly negative in 410 different regions of the $A$. xanthosoma mitochondrial genome (Table 3 ). An investigation of 411 nucleotide skew statistics for the mitochondrial genome of $A$. xanthosoma revealed that PCGs in 412 both strands were T-skewed, whereas the PCGs were C-skewed in the J-strand and G-skewed in 413 the N-strand.

414 Codon usage of the A. xanthosoma mitochondrial genome was shown in Table 4. We observed a 415 relationship between the base composition of codon families and amino acid occurrence, which 416 was assessed by calculating the number of $\mathrm{G}+\mathrm{C}$-rich codons (Pro, Ala, Arg, and Gly) and A+T417 rich codons (Phe, Ile, Met, Tyr, Asn, and Lys) and then calculating their ratio (Crozier \& 418 Crozier, 1993). In A. xanthosoma, this ratio was 0.16 , which was lower than that in $M$. pruni 419 (Wei et al., 2015).

420 After several calculations, multiple observations were made. UUA-Leu had the highest RSCU, 421 with an average value of 3.84. In addition, all codons with an RSCU greater than 2.00 had an A 422 at the third codon position (Table 4). The A content of the third codon position was higher than 423 that of the first codon position and lower than that of second codon positions in PCGs (Table 3). 424 We therefore concluded that the nucleotide composition was closely related to codon usage.

\section{Transfer RNA genes}

428

The mitochondrial genome of $A$. xanthosoma contains 22 tRNA genes. Fourteen of the 22 tRNA genes were located on the J-strand, while the remaining were encoded by the opposite N-strand.

430

431

432

433

434

435

436

437

438

439

440

441

442

443

444 The length of the tRNAs ranged from $64 \mathrm{bp}(\operatorname{trn} A)$ to $71 \mathrm{bp}(\operatorname{trn} K, \operatorname{trn} V)$. All predicted secondary structures of the tRNAs had a common cloverleaf pattern, with the exception of trnSl (AGN), where the DHU arm was missing. Predicted secondary structures of the 22 tRNA genes were shown in Figure 6.

The size of the variable loop and D-loop often determines the overall tRNA length (Navajas et al., 2002). In the secondary structure of the tRNAs of the A. xanthosoma mitochondrial genome, the DHU arms ranged between 3 and 4 bp in length, the AC arms ranged between 4 and 5 bp in

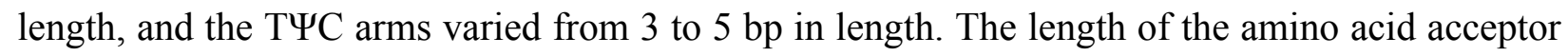
(AA) stem was conserved at $7 \mathrm{bp}$ in all of the tRNA genes. The anticodon (AC) loops were usually $7 \mathrm{bp}$ in length. The length of the variable loops was less consistent, ranging from 4 to 7 bp.

The variable loops in $\operatorname{trn} D, \operatorname{trn} F, \operatorname{trn} G, \operatorname{trn} H$ and $\operatorname{trn} T$ were completely conserved between $A$. xanthosoma and $M$. pruni and differed from those in Allantus luctifer, A. rufocephalus, Tenthredo tienmushana and Birmella discoidalisa. The AC loop in trnC, TYC loop in trnS2,

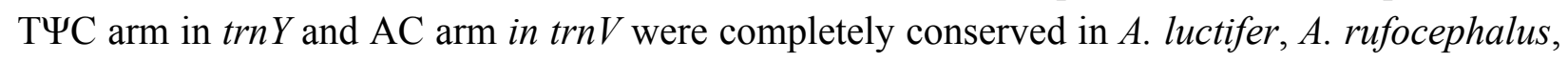
T. tienmushana, A. xanthosoma and M. pruni, while those in B. discoidalisa were different. The 
445 base between the DHU arm and $\mathrm{AC}$ arm in trnS2 was $\mathrm{A}$ in A. xanthosoma, $M$. pruni, and $B$. 446 discoidalisa, while the base was $\mathrm{U}$ in A. luctifer, A. rufocephalus and T. tienmushana.

447 A total of 21 unmatched base pairs were scattered throughout the 22 tRNA genes, including 13 448 pairs in the AA stems, five pairs in the DHU stems and three pairs in the TYC stems. Fourteen of 449 these unmatched base pairs were G-U pairs, which formed a stable hydrogen-bonded pair. The 450 remaining unmatched pairs were U-U (6) and A-A (1) mismatches. The phenomenon of aberrant 451 mismatches, loops, or extremely short arms for tRNA is common in metazoan mitochondrial 452 genomes (Wolstenholme, 1992). Although whether the aberrant tRNAs have lost their respective 453 functions is still unknown, such loss can be corrected by post-transcriptional RNA-editing 454 processes (Lavrov, 2000; Masta \& Boore, 2004).

455

456

457

458

459

460

461

462

463

464

465

466

467

468

469

470

471

472

473

474

475

476

477

478

479

480

481

482

483

484

485

\section{Ribosomal RNA genes}

The $r r n L$ gene was 1336 bp in length with an $83.4 \% \mathrm{~A}+\mathrm{T}$ content, while $r r n S$ was $800 \mathrm{bp}$ in length with an $82.4 \% \mathrm{~A}+\mathrm{T}$ content (Table 2). In addition, $r r n L$ was located between $\operatorname{trnL} 1$ and $\operatorname{trnV} ; r r n S$ was located downstream of $\operatorname{trnV}$. The secondary structures of $r r n L$ and $r r n S$ are shown in Figure 7 and Figure 8.

Forty-four helices belonging to six domains were identified in the $r r n L$ secondary structure of $A$. xanthosoma, similar to the findings for A. mellifera (Gillespie et al., 2006). In $r r n L$, domains IV and V were more conserved within the Tenthredinidae family. Eight helices (H563, H1775, H1830, H1925, H2023, H2043, H2547 and H2588) were highly conserved. Furthermore, some helices (H837, H991, H1196 and H2347) were highly variable in terms of their sequence and secondary structure compared with other insects (Gillespie et al., 2006; Du et al., 2018; Niu et al.. 2019; Castro and Dowton, 2005; Dowton et al., 2009). Compared with A. mellifera, which harbored an A at position 75 (H235), an A at position 238 (H671) and an A at position 733 in H1835, A. luctifer, A. rufocephalus and T. tienmushana harbored a $\mathrm{U}$ at each site. $\mathrm{H} 736$ and H1764 were completely conserved in helices between A. xanthosoma and M. pruni but variable in A. luctifer, A. rufocephalus, T. tienmushana and B. discoidalisa. $\mathrm{H} 687$ was highly conserved in helices between A. xanthosoma and M. pruni, with only one change (an A at position 255 changed to a G). The $\mathrm{H} 777$ in B. discoidalisa was different from that in A. luctifer, A. rufocephalus, T. tienmushana, A. xanthosoma and M. pruni. Additionally, a $\mathrm{U}$ at position 342 was changed to a $\mathrm{G}$ in $B$. discoidalisa, and a $\mathrm{U}$ at position 510 in $\mathrm{H} 1087$ was changed to a $\mathrm{C}$ in $B$. discoidalisa. H822 was completely conserved in A. luctifer, A. rufocephalus, T. tienmushana and B. discoidalisa, while the G-C was replaced by a Watson-Crick A-U pair at positions 347-357. H1057 was conserved between A. xanthosoma and M. pruni, while it was variable in A. luctifer, A. rufocephalus, T. tienmushana and B. discoidalisa.

A. xanthosoma also expressed $r r n S$ with 26 helices in four domains, consistent with the pattern observed in Zygaenoidea (Niehuis et al., 2006). Specifically, H47 was variable among the different hymenopteran species, having a large loop. The loop size was variable and determined by the overall $r r n S$ length. The H769 and H1399 were more similar to those of A. mellifera characterized by Gillespie (2006) than to other helices. In $r r n S$, domain III was more conserved within Tenthredinidae than domains I, II, and VI. The loop between H39 and H47, the loop

Peer) reviewing PDF | (2018:09:31616:3:1:NEW 2 Mar 2019) 
486 between $\mathrm{H} 984$ and $\mathrm{H} 1047$ at positions 497-491, as well as the H367 loop were completely 487 conserved between $A$. xanthosoma and $M$. pruni but variable among A. luctifer, A. rufocephalus, 488 T. tienmushana and B. discoidalisa. Compared with A. xanthosoma and M. pruni, a C at position 489169 was changed to a $\mathrm{U}$, a $\mathrm{U}$ at position 461 was changed to a A and a $\mathrm{U}$ at position 658 was 490 changed to a $\mathrm{G}$ in A. luctifer, A. rufocephalus, T. tienmushana and B. discoidalisa. Similarly, a 491 C-G pair was replaced by a C-G pair at positions 510-573 in A. luctifer, A. rufocephalus and T. 492 tienmushana.

493 The secondary structures of $r r n L$ and $r r n S$ agreeded with the BI and ML analyses that $A$. 494 xanthosoma + M. pruni is a sister group to (( A. luctifer + A. rufocephalus $)$ T. tienmushana) $B$. 495 discoidalisa).

496 Phylogenetic relationships

497 To investigate the phylogenetic relationships within Symphyta, we analyzed 27 symphytan and 498 two apocritan mitochondrial genomes. Genomes from four species were also used as outgroups 499 (Mecoptera, Diptera, Megaloptera, and Coleoptera) (Table 1). The 27 species of Symphyta 500 represented eight families: Tenthredinidae (Wei et al., 2014, 2015; Song et al., 2015, 2016), 501 Cimbicidae (Song et al., 2016; Doğan \& Korkmaz, 2017; Yan et al., in press), Pergidae (Castro 502 and Dowton, 2005), Orussidae (Dowton et al., 2009), Cephidae (Dowton et al., 2009; Korkmaz 503 et al., 2015, 2016, 2017, 2018), Argidae (Du et al., 2018), Megalodontesidae, and Pamphiliidae 504 (Niu et al. 2019).

505 Phylogenetic relationships within the suborder Symphyta were reconstructed using both BI and 506 ML analyses (Figure 9). They both grouped $A$. xanthosoma with $M$. pruni and revealed that $A$. 507 xanthosoma + M. pruni is a sister group to (( A. luctifer + A. rufocephalus $) T$. tienmushana) $B$. 508 discoidalisa) and that Tenthredinidae forms a sister group with Cimbicidae. The systematic 509 position of Analcellicampa + Monocellicampa within Tenthredinidae (= Tenthredinoidea sensu 510 Wei \& Nie, 1998) agreed with the system of Wei \& Nie (1998). Although there were some 511 differences in our results between the two analytical methods, our findings largely agreed with 512 traditional morphological classifications and recent molecular studies. Additionally, we 513 demonstrated that mitochondrial genome sequences can be used to solve phylogenetic 514 relationships at different taxonomic levels within Symphyta.

515 However, the relationship between Analcellicampa + Monocellicampa and other taxa of

516 Nematinae needs further study as no mitochondrial genome has been sequenced for any member 517 of Susanini, Cladiini or Nematini.

518

519 CONCLUSIONS

520 Analcellicampa is a peculiar new genus of Hoplocampinae and is closely allied to 521 Monocellicampa Wei. Analcellicampa gen. nov. differs from the latter by the following 522 characteristics: anal cell of the hind wing broadly opened at apex, the epicnemium large with a 523 distinct epicnemial suture, the third tooth of the mandibles obtuse, the inner tibial spur of the 524 foreleg simple with a membranous lobe far from the apex and the valviceps of the penis valve 525 without a stout valvispina but with many small surface teeth. A. xanthosoma sp. nov. differs 
526 from $A$. danfengensis (Xiao, 1994) comb. nov. by the following: the thorax, abdomen and legs 527 almost entirely yellow-brown, the wings hyaline with the pterostigma and veins pale brown, the 528 postocellar area approximately 3 times as broad as long, very long and slender cerci 529 approximately 10 times as long as broad, the ovipositor apical sheath 1.6 times as long as the 530 basal sheath and the basal 10 annular sutures of the lancet distinct.

531 The nearly complete mitochondrial genome of A. xanthosoma was obtained and found to have a 532 length of $15512 \mathrm{bp}$ and 37 genes (22 tRNAs, 13 PCGs, and two rRNAs). The gene order was the 533 same as its ancestral type. The secondary structures of 22 tRNAs and two rRNAs resembled 534 those of Symphyta, but some helices (H837, H991, H1196 and H2347) were highly variable in $535 r r n L$. The secondary structure of $r r n L$ remains to be studied. Finally, phylogenetic reconstruction 536 based on mitochondrial genomes (13 PCGs and two rRNAs) revealed similarly high support $537(100 \%)$ in both BI and ML analyses, with the result that A. xanthosoma was sister to M. pruni. 538 We suggest that $A$. xanthosoma as well as $M$. pruni belongs to the tribe Hoplocampini of Hoplocampinae based on adult morphology and molecular data from the mitochondrial genome.

ACKNOWLEDGMENTS

542 The members of the Lab of Insect Systematics and Evolutionary Biology (LISEB) from Central 543 South University of Forestry and Technology are thanked for their contributions to laboratory 544

545

546

547

548

549

550

551

552

553

554

555

556

557

558

559

560

561

562

563

564 work. We thank all the reviewers for their comments.

\section{REFERENCES}

Abe M, Smith DR. 1991. The Genus-group Names of Symphyta (Hymenoptera) and Their Type Species. Esakia 31:1-115.

Ashmead WH. 1898a. Classification of the horntails and sawflies or the Suborder Phytophaga Family XII-Nematidae. The Canadian Entomologists 30:281-287.

Ashmead WH. 1898b. Classification of the Horntails and Sawflies, or the Suborder Phytophaga (Paper No. 5). The Canadian Entomologist, London 30(10):249-257.

Benson RB. 1938. On the classification of Sawflies (Hymenoptera, Symphyta). Transactions of the Entomological Society of London 87:353-384.

Benson RB. 1958. Hymenoptera 2.Symphyta (c). Handbooks for the identification of British insects 6(2c):139-252.

Beard CB, Hamm DM, Collins FH. 1993. The mitochondrial genome of the mosquito Anopheles gambiae: DNA sequence, genome organization, and comparisons with mitochondrial sequences of other insects. Insect Molecular Biology 2(2):103-124.

Bernt M, Donath A, Jühling F, Externbrink F, Florentz C, Fritzsch G, Pütz J, Middendorf M, Stadler PF. 2013. MITOS: improved de novo metazoan mitochondrial genome annotation. Molecular Phylogenetics \& Evolution 69:313-319.

Cameron P. 1882. A monograph of the British Phytophagous Hymenoptera (Tenthredo, Sirex, Cynips Linné). London. Ray Cociety 1:1-340. 
565 Cameron SL. 2014. Insect mitochondrial genomics: implications for evolution and phylogeny.

566

567

568

569

570

571

572

573

574

575

576

577

578

579

580

581

582

583

584

585

586

587

588

589

590

591

592

593

594

595

596

597

598

599

600

601

602

603

604

605

Annual Review of Entomology 59:95-117.

Castro LR, Dowton M. 2005. The position of the Hymenoptera within the Holometabola as inferred from the mitochondrial genome of Perga condei (Hymenoptera: Symphyta: Pergidae). Molecular Phylogenetics and Evolution 34(3):469-479.

Crozier RH, Crozier YC. 1993. The mitochondrial genome of the honeybee Apis mellifera: Complete sequence and genome organization. Genetics 133:97-117.

Dalla Tolle CG. 1894. Catalogus Hymenopterorum Hucusque descriptorum systematicus et synonymicus Vol. I. Tenthredinidae incl. Uroceridae (Phyllophaga \& Xylophaga). Lipsiae (Engelmann), VIII +459 pp.

Darty K, Denise A, Ponty Y. 2009. VARNA: Interactive drawing and editing of the RNA secondary structure. Bioinformatics 25:1974-1975.

De Rijk P, Wuyts J, De Wachter R. 2003. RnaViz 2: an improved representation of RNA secondary structure. Bioinformatics (Oxford, England) 19:299-300.

Dierckxsens N, Mardulyn P, Smits G. 2017. NOVOPlasty: de novo assembly of organelle genomes from whole genome data. Nucleic Acids Research 45:18.

Doğan Ö, Korkmaz EM. 2017. Nearly complete mitogenome of hairy sawfly, Corynis lateralis (Brullé, 1832) (Hymenoptera: Cimbicidae): rearrangements in the IQM and ARNS1EF gene clusters. Genetica 145:341-350.

Dowton M, Cameron SL, Austin AD, Whiting MF. 2009. Phylogenetic approaches for the analysis of mitochondrial genome sequence data in the Hymenoptera-a lineage with both rapidly and slowly evolving mitochondrial genomes. Molecular Phylogenetics \& Evolution 52:512-519.

Du S, Niu G, Nyman T, Wei M. 2018. Characterization of the mitochondrial genome of Arge bella Wei \& Du sp. nov. (Hymenoptera: Argidae). PeerJ 6:e6131.

Enslin E. 1918. Die Tenthredinoidea Mitteleuropas. VII. Dt. Ent. Z. (Beihefte.) 663-790.

Gillespie JJ, Johnston JS, Cannone JJ, Gutell RR. 2006. Characteristics of the nuclear (18S, 5.8S, $28 \mathrm{~S}$ and $5 \mathrm{~S}$ ) and mitochondrial (12S and 16S) rRNA genes of Apis mellifera (Insecta: Hymenoptera): structure, organization, and retrotransposable elements. Insect molecular biology 15:657-686.

Hahn C, Bachmann L, Chevreux B. 2013. Reconstructing mitochondrial genomes directly from genomic next-generation sequencing reads-a baiting and iterative mapping approach. Nucleic Acids Research 41:129.

Hassanin A, Léger N, Deutsch J. 2005. Evidence for multiple reversals of asymmetric mutational constraints during the evolution of the mitochondrial genome of metazoa, and consequences for phylogenetic inferences. Systematic Biology 54:277-298.

Hyde J, Cooper SJB, Munguia P, Humphreys WF, Austin AD. 2018. The first complete mitochondrial genomes of subterranean dytiscid diving beetles (Limbodessus and Paroster) from calcrete aquifers of Western Australia. Australian Journal of Zoology 65:283-291.

Katoh K, Standley DM. 2013. MAFFT multiple sequence alignment software version 7: improvements in performance and usability. Molecular biology and evolution 30:772-80.

PeerJ reviewing PDF | (2018:09:31616:3:1:NEW 2 Mar 2019) 
606 Kirby WF. 1882. List of Hymenoptera, with description and figures of the typical specimens in

607

608

609

610

611

612

613

614

615

616

617

618

619

620

621

622

623

624

625

626

627

628

629

630

631

632

633

634

635

636

637

638

639

640

641

642

643

the British Museum, I. Tenthredinidae and Siricidae. London, $450 \mathrm{pp}$.

Konow FW. 1905. Hymenoptera, Family Tenthredinidae. In P. wytsman (Ed.). Genera Insectorum, fasc. 29, Bruxelles. 176pp.

Korkmaz EM, Doğan Ö, Durel BS, Temel Altun B, Budak M, Başıüyük HH. 2018. Mitogenome organization and evolutionary history of the subfamily Cephinae (Hymenoptera: Cephidae). Systematic Entomology 43(3):606-618.

Korkmaz EM, Aydemir HB, Temel B, Budak M, Başıüyük HH. 2017. Mitogenome evolution in Cephini (Hymenoptera: Cephidae): Evidence for parallel adaptive evolution. Biochemical Systematics and Ecology 71:137-146.

Korkmaz EM, Budak M, Ördek MN, Başibüyük HH. 2016. The complete mitogenomes of Calameuta filiformis (Eversmann, 1847) and Calameuta idolon (Rossi, 1794) (Hymenoptera:

Cephidae): The remarkable features of the elongated $\mathrm{A}+\mathrm{T}$ rich region in Cephini. Gene 576:404-411.

Korkmaz EM, Doğan Ö, Budak M, Başibüyük HH. 2015. Two nearly complete mitogenomes of wheat stem borers, Cephus pygmeus (L.) and Cephus sareptanus Dovnar-Zapolskij (Hymenoptera: Cephidae): An unusual elongation of rrnS gene. Gene 558:254-264.

Kumar S, Stecher G, Tamura K. 2016. MEGA7: Molecular Evolutionary Genetics Analysis version 7.0 for bigger datasets. Molecular Biology \& Evolution 33:1870.

Lanfear R, Calcott B, Ho SYW, Guindon S. 2012. PartitionFinder: Combined selection of partitioning schemes and substitution models for phylogenetic analyses. Molecular Biology and Evolution 29:1695-1701.

Lavrov D V. 2000. A Novel Type of RNA Editing Occurs in the Mitochondrial tRNAs of the Centipede Lithobius forficatus. Proceedings of the National Academy of Sciences of the United States of America 97(25):13738-13742.

Li H, Liu H, Cao L, Shi A, Yang H, Cai W. 2012. The Complete Mitochondrial Genome of the Damsel Bug Alloeorhynchus bakeri (Hemiptera : Nabidae ). International Journal of Biological Sciences 8(1):93-107.

Li Z. \& Wei MC. 2012. Two new species of Nematinae from Mt. Helan of Inner Mongolia (Hymenoptera, Tenthredinidae). Acta Zootaxonomica Sinica 37(1):176-180.

Liu T, Liu L, Wei MC. Review of Monocellicampa Wei (Hymenoptera: Tenthredinidae), with Description of a New Species from China. Proceedings of the Entomological Society of Washington 119(1):70-77.

Liu T, Niu G, Wei MC. 2018. A New Genus and a New Species of Anhoplocampini from China (Hymenoptera: Tenthredinidae). Proceedings of the Entomological Society of Washington 119 (Special Issue):801-806.

Liu M, Li ZJ, Wei MC, Niu, G. 2018a. A new species from the Nematus lucidus group (Hymenoptera: Tenthredinidae) in China. Entomotaxonomia 40(1):1-6. 
644 Liu M, Li ZJ, Yan J, Wei MC, Niu G. 2018b. A new species of Stauronematus Benson

645

646

647

648

649

650

651

652

653

654

655

656

657

658

659

660

661

662

663

664

665

666

667

668

669

670

671

672

673

674

675

676

677

678

679

680

681

682

683

684

(Hymenoptera: Tenthredinidae), Which is a defoliator of Populus $\times$ canadensis in China. Scientia Silvae Sinicae 54(6):94-99.

Luo R, Liu B, Xie Y, Li Z, Huang W, Yuan J, He G, Chen Y, Qi P, Liu Y. 2012. SOAPdenovo2: an empirically improved memory-efficient short-read de novo assembler. Gigascience 1:18.

Macgillivray AD. 1906. A study of the wings of the Tenthredinoidea, a superfamily of Hymenoptera. Proceedings of the United States National Museum 29:569-654, 97 figs.

Malaise R. 1963. Hymenoptera Tenthredinoidea subfamily Selandriinae, key to the genera of the World. Entomologisk Tidskrift, Stockholm 84(3-4):159-215.

Masta SE, Boore JL. 2004. The Complete Mitochondrial Genome Sequence of the Spider Habronattus oregonensis Reveals Rearranged and Extremely Truncated tRNAs. Molecular Biology \& Evolution 21:893-902.

Maxwell DE. 1955. The Comparative Internal Larval Anatomy of Sawflies (Hymenoptera: Symphyta)1. Memoirs of the Entomological Society of Canada 87:1-132.

Navajas M, Le CY, Solignac M, Cros-Arteil S, Cornuet JM. 2002. The complete sequence of the mitochondrial genome of the honeybee ectoparasite mite Varroa destructor (Acari: Mesostigmata). Molecular Biology \& Evolution 19:2313.

Nawrocki EP. 2009. Structural RNA homology search and alignment using covariance models. Washington University in St. Louis.

Niehuis O, Naumann CM, \& Misof, B. 2006. Identification of evolutionary conserved structural elements in the mt SSU rRNA of Zygaenoidea (Lepidoptera): A comparative sequence analysis.Organisms Diversity \& Evolution 6(1):17-32.

Niu G, Korkmaz EM, Doğan Ö, Zhang YY, Aydemir MN, Budak M, Du SY, Başıbüyük HH, Wei MC. 2019. The first mitogenomes of the superfamily Pamphilioidea (Hymenoptera: Symphyta): Mitogenome architecture and phylogenetic inference. International Journal of Biological Macromolecules 124:185-199.

Nyman T, Zinovjev AG, Vikberg V, Farrell BD. 2006. Molecular phylogeny of the sawfly subfamily Nematinae (Hymenoptera: Tenthredinidae). Systematic Entomology 31:569-583.

Perna NT, Kocher TD. 1995. Patterns of nucleotide composition at fourfold degenerate sites of animal mitochondrial genomes. Journal of Molecular Evolution 41:353-358.

Peng Y, Chen B, LI TJ. 2017. Sequencing and analysis of the complete mitochondrial genome of Parapolybia crocea (Hymenoptera: Vespidae). Acta Entomologica Sinica 60(4):464-474.

Prous, Blank SM, Goulet H, Heibo E, Liston A, Malm T, Nyman T, Schmidt S, Smith DR, Vardal H. 2014a. The genera of Nematinae (Hymenoptera, Tenthredinidae). Journal of Hymenoptera Research 40:1-69.

Rohwer SA. 1911. A Classification of the Suborder Chalastogastra of Hymenhoptera. Proceedings of the Entomological Society of Washington 13:215-226.

Rohwer SA. 1912. Notes on sawflies, with descriptions of new species. Proceedings of the United States National Museum 43(1930):205-251, 6 figs.

Rohwer SA, Middleton W. 1932. Descriptions of five new Nearctic sawflies of the tribe Hemichroini. Proceedings of the entomological Society of Washington 34(6):93-98.

Peer) reviewing PDF | (2018:09:31616:3:1:NEW 2 Mar 2019) 
685 Ronquist F, Teslenko M, Van Der Mark P, Ayres DL, Darling A, Höhna S, Larget B, Liu L,

686

687

688

689

690

691

692

693

694

695

696

697

698

699

700

701

702

703

704

705

706

707

708

709

710

711

712

713

714

715

716

717

718

719

720

721

722

723

724

725 and model choice across a large model space. Systematic Biology 61:539-542.

Ross HH. 1937. A Generic Classification of the Nearctic Sawflies (Hymenoptera: Symphyta). Illinois biological monographs Urbana 15(2):1-173.

Ross HH. 1945. Sawfly genitalia: terminology and study techniques. Entomological News 61(10):261-268.

Ross HH. 1951. Suborder Symphyta (= Chalastogastra) [except the Siricoidea, the Pamphiliidae, and the genus Periclista]. In: Muesebeck, C.F.W. Krombein, K.V. \& Townes, H.K, Hymenoptera of America North of Mexico - Synoptic Catalog. United States Department of Agriculture Agriculture Monograph Vol. 2, pp. 4-89.

Siebert S, Backofen R. 2005. MARNA: multiple alignment and consensus structure prediction of RNAs based on sequence structure comparisons. Bioinformatics 21:3352.

Smith DR, Burks BD. 1979. Catalog of Hymenoptera in America north Mexico. Vol. I. Symphyta and Apocrita (Parasitica). Smithsonian Institution Press, Washington, D. C, p.1-137.

Song SN, Tang P, Wei SJ, Chen XX. 2016. Comparative and phylogenetic analysis of the mitochondrial genomes in basal hymenopterans. Scientific Reports 6(1):20972-20972.

Song SN, Wang ZH, Li Y, Wei SJ, Chen XX. 2015. The mitochondrial genome of Tenthredo tienmushana (Takeuchi) and a related phylogenetic analysis of the sawflies (Insecta: Hymenoptera). Mitochondrial DNA:1-2.

Sun YZ, Jiang BB. 1994. The biology and control of Fenusa sp.. Entomological Knowledge:1719.

Taeger A, Blank SM, Liston AD. 2010. World catalog of Symphyta (Hymenoptera). Zootaxa 2580:1-1064.

Takeuchi K. 1952. A Generic Classification of the Japanese Tenthredinidae (Hym.: Symphyta). Kyoto:1-90.

Viitasaari, M. 2002. Sawflies (Hymenoptera, Symphyta) I. A review of the suborder, the Western Palaearctic taxa of Xyeloidea and Pamphilioidea. Helsinki Tremex Press Ltd. 1-516.

Vaidya G, Lohman DJ, Meier R. 2011. SequenceMatrix: Concatenation software for the fast assembly of multi-gene datasets with character set and codon information. Cladistics 27:171180.

Wei MC, Nie H. 1998. Generic list of Tenthredinoidea s. str. (Hymenoptera) in new systematic arrangement with synonyms and distribution data. Journal of Central South Forestry University 18:23-31.

Wei MC, Niu G. 2011. Review of Anhoplocampa Wei (Hymenoptera, Tenthredinidae), with description of a new species and a new combination. Zookeys 159:81-90.

Wei MC, Xia GC. 2012. A new species of Pristiphora (Hymenoptera, Tenthredinidae) feeding on Larix from China. Acta Zootaxonomica Sinica 37:171-174.

Wei MC. 1998. Two new genera of Hoplocampinae (Hymenoptera: Nematidae) from China with a key to known genera of the subfamily in the world. Journal of Central South University 18 (4):12-18.

Peer] reviewing PDF | (2018:09:31616:3:1:NEW 2 Mar 2019) 
726

727

728

729

730

731

732

733

734

735

736

737

738

739

740

741

742

743

744

745

746

747

748

749

750

751

752

753

754

755

756

757

758

759

760

761

762

763

764

765

Wei SJ, Wu QL, Liu W. 2015. Sequencing and characterization of the Monocellicampa pruni (Hymenoptera: Tenthredinidae) mitochondrial genome. Mitochondrial DNA 26:157-158.

Wei SJ, Niu FF, and Du BZ. 2014. Rearrangement of trnQ-trnM in the mitochondrial genome of Allantus luctifer (Smith) (Hymenoptera: Tenthredinidae) Rearrangement of trnQ-trnM in the mitochondrial genome of Allantus. Mitochondrial DNA A DNA Mapp Seq Anal 27(2):856858.

Wu QL, Li Q, Gu Y, Shi BC, van Achterberg C, Wei SJ, Chen XX. 2014. The complete mitochondrial genome of Taeniogonalos taihorina (Bischoff) (Hymenoptera: Trigonalyidae) reveals a novel gene rearrangement pattern in the Hymenoptera. Gene 543:76-84.

Wolstenholme DR. 1992. Animal mitochondrial DNA: structure and evolution. International Review of Cytology 141:173.

Xiao G. 1994. A new sawfly injurious to cherry from China (Hymenoptera: Tenthredinidae). Scientia Silvae Sinicae 30:442-444.

Zhao Y, Zhang H, Zhang Y. 2017. Complete mitochondrial genome of Neochauliodes parasparsus (Megaloptera: Corydalidae) with phylogenetic consideration. Biochemical Systematics \& Ecology 70:192-199.

Zhelochovtsev AH. 1988, 27. Order Hymenoptera. Suborder Symphyta (Chalastogastra). In Opredelitel naseomych evropejskoj casti SSSR, Tom 3. Hymenoptera, pt. 6. Leningrad, pp. 7234.

Zinovjev AG. 2000. Supplements and correctons to the list of sawflies (Hymenoptera, Symphyta) of the fauna of Russia and adjacent territories. Entomologicheskoe obozrenie 79:450-457.

\section{Notes}

Table 1. Summary of symphytan mitogenomes used in phylogenetic analyses.

Figure 1. Analcellicampa xanthosoma.

Adult female, dorsal view. Scale bar $=1 \mathrm{~mm}$. Photos: Yaoyao Zhang.

Figure 2. Analcellicampa xanthosoma.

a. Head of female, dorsal view; b. Head of female, front view; c. Head of female, lateral view; $d$. Scutellum of female; e. Abdominal tergum 1; f. Mesopleuron of female, lateral view; g. Ovipositor sheath of female, lateral view; h. Cercus of female; i. Middle serrulae of female; $j$. Claw of female; k. Lancet of female; 1. Antenna of female. Photos: Yaoyao Zhang.

Figure 3. Analcellicampa danfengensis (Xiao).

a. Female, dorsal view; b. Male, dorsal view; c. Head of female, front view; d. Mesopleuron, female; e. Ovipositor sheath, lateral view; f. Head of female, dorsal view; g. Lancet; h. Middle serrulae; i. Gonoharpe; j. Penis valve; k. Valviceps of penis valve. Scale bars $=1 \mathrm{~mm}$. Photos: Meicai Wei.

Figure 4. Analcellicampa danfengensis (Xiao). Female

a. Forewing; b. Hindwing; c. Maxilla; d. Labrum; e. Inner fore tibial spur; f. Claw; g. Left mandible; h. Right mandible; i. Antenna; j. Fore tibia and tarsus. Photos: Meicai Wei.

Table 2. Mitochondrial genome characteristics of Analcellicampa xanthosoma.

Peer) reviewing PDF | (2018:09:31616:3:1:NEW 2 Mar 2019) 
766 J, major; N, minor; IGN, intergenic nucleotides. Minus indicates overlapping sequences between 767 adjacent genes.

768 Figure 5. Mitochondrial genome organization of Analcellicampa xanthosoma.

769 Mitochondrial genome organization of $A$. xanthosoma with reference to the ancestral type of 770 insect mitochondrial genomes. Genes transcribed from the J- and N-strands are shown in green

771 and orange, respectively. Overlapping and intergenic regions are indicated by yellow and blue 772 circles, respectively. The A+ T-rich region is indicated by blue, and tRNA genes are labeled by 773 their single-letter amino acid code.

774 Table 3. Nucleotide composition of the Analcellicampa xanthosoma mitochondrial genome.

775 Table 4. Codon usage of 13 PCGs in the mitochondrial genome of Analcellicampa xanthosoma.

776 No, frequency of each codon; RSCU, relative synonymous codon usage.

777 Figure 6. Predicted secondary structures of 22 tRNA genes of $A$. xanthosoma.

778 Dashes indicate Watson-Crick base pairs, and dots indicate G-U base pairing.

779 Figure 7. Predicted $r r n L$ secondary structure in the A. xanthosoma mitochondrial genome.

780 The numbering of helices follows Gillespie et al. (2006). Roman numerals refer to domain 781 names.

782 Figure 8. Predicted $r r n S$ secondary structure in the A. xanthosoma mitochondrial genome.

783 The numbering of helices follows Gillespie et al. (2006). Roman numerals refer to domain 784 names.

785 Figure 9. Symphytan phylogenetic tree constructed with BI and ML approaches using a 786 mitogenome dataset including 15 individual genes (13 PCGs and two rRNAs).

787 Both analyses produced the same tree topology. Support values lower than $100 \%$ in the ML 788 analysis and 1.0 in the $\mathrm{BI}$ analysis were shown. 


\section{Figure 1}

Analcellicampa xanthosoma.

Adult female, dorsal view. Scale bar $=1 \mathrm{~mm}$. Photos: Yaoyao Zhang.

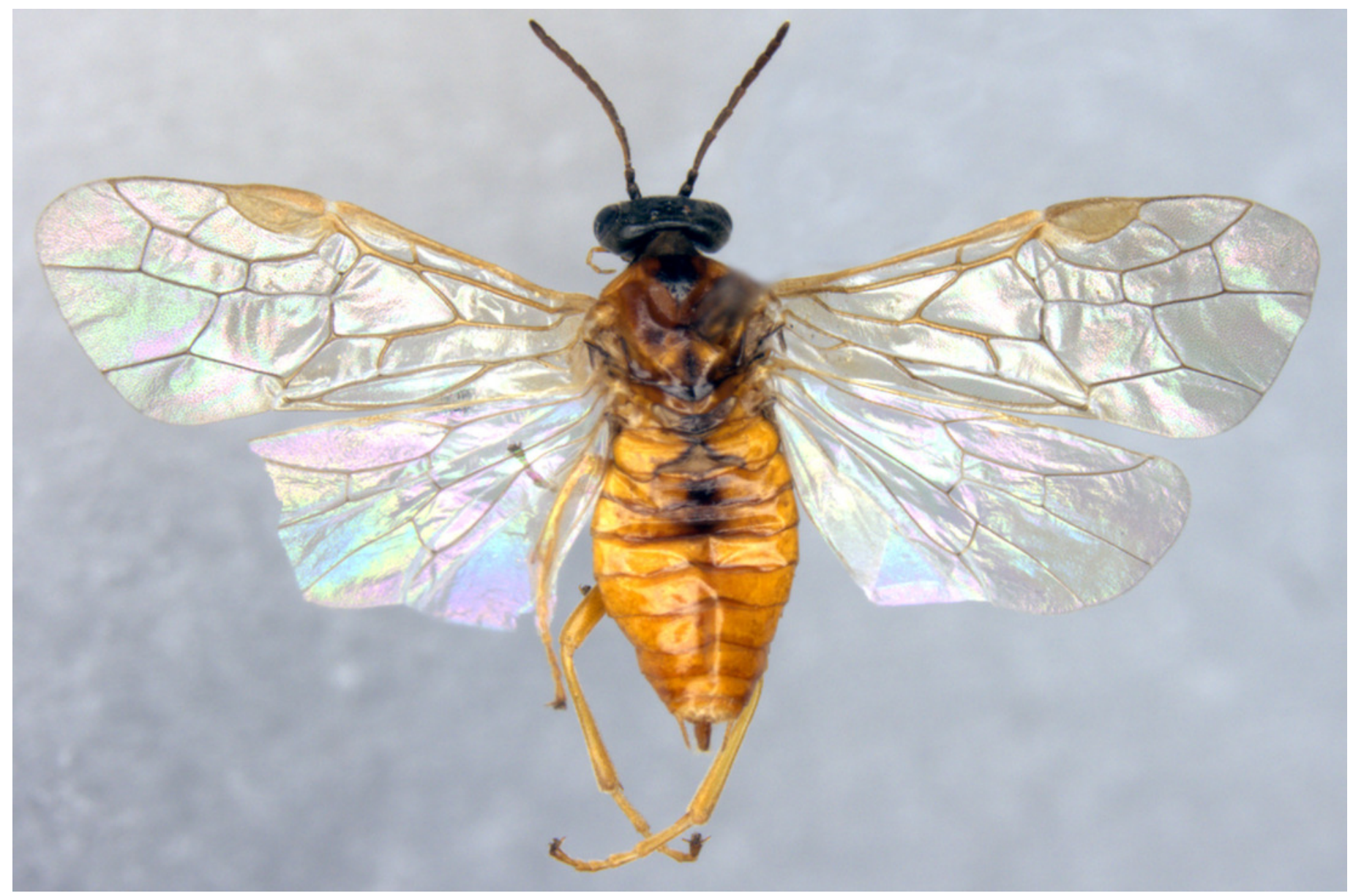


Figure 2

Analcellicampa xanthosoma.

a. Head of female, dorsal view; b. Head of female, front view; c. Head of female, lateral view;

d. Scutellum of female; e. Abdominal tergum 1; f. Mesopleuron of female, lateral view; $g$.

Ovipositor sheath of female, lateral view; h. Cercus of female; i. Middle serrulae of female; j.

Claw of female; k. Lancet of female; I. Antenna of female. Photos: Yaoyao Zhang. 


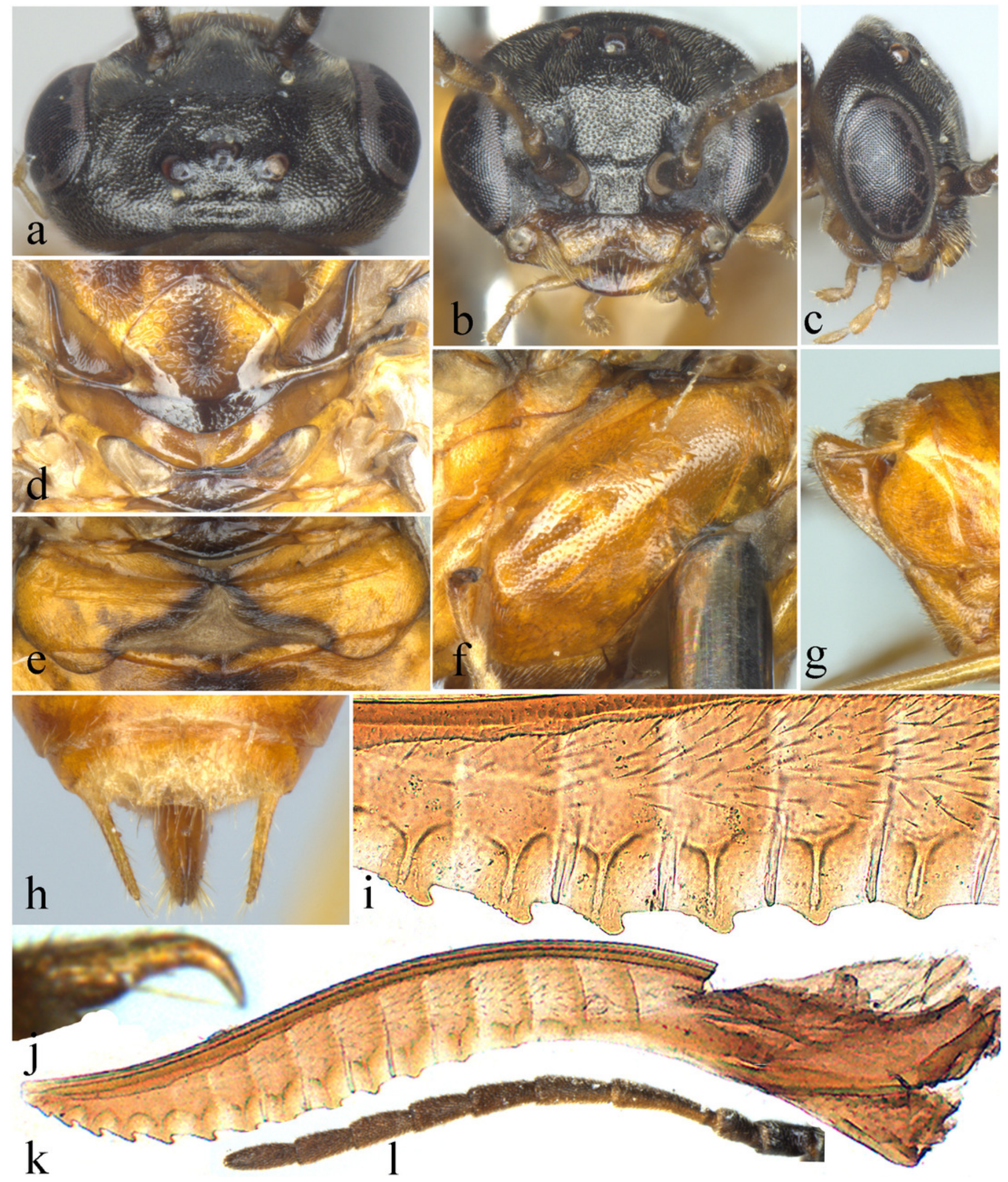


Figure 3

Analcellicampa danfengensis (Xiao).

a. Female, dorsal view; b. Male, dorsal view; c. Head of female, front view; d. Mesopleuron, female; e. Ovipositor sheath, lateral view; f. Head of female, dorsal view; g. Lancet; h. Middle serrulae; i. Gonoharpe; j. Penis valve; k. Valviceps of penis valve. Scale bars $=1 \mathrm{~mm}$. Photos: Meicai Wei. 

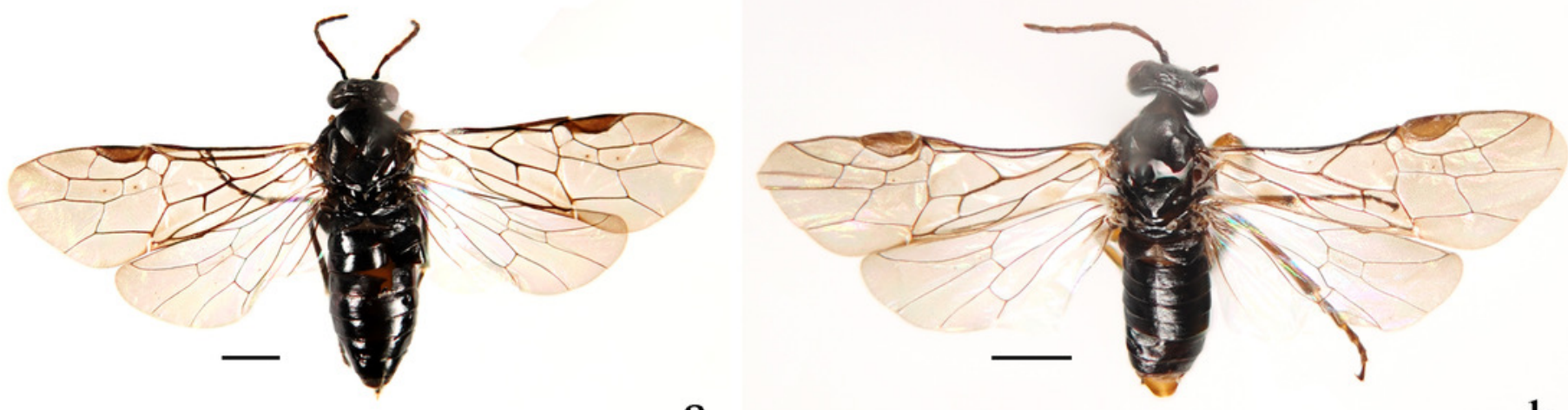

a

b
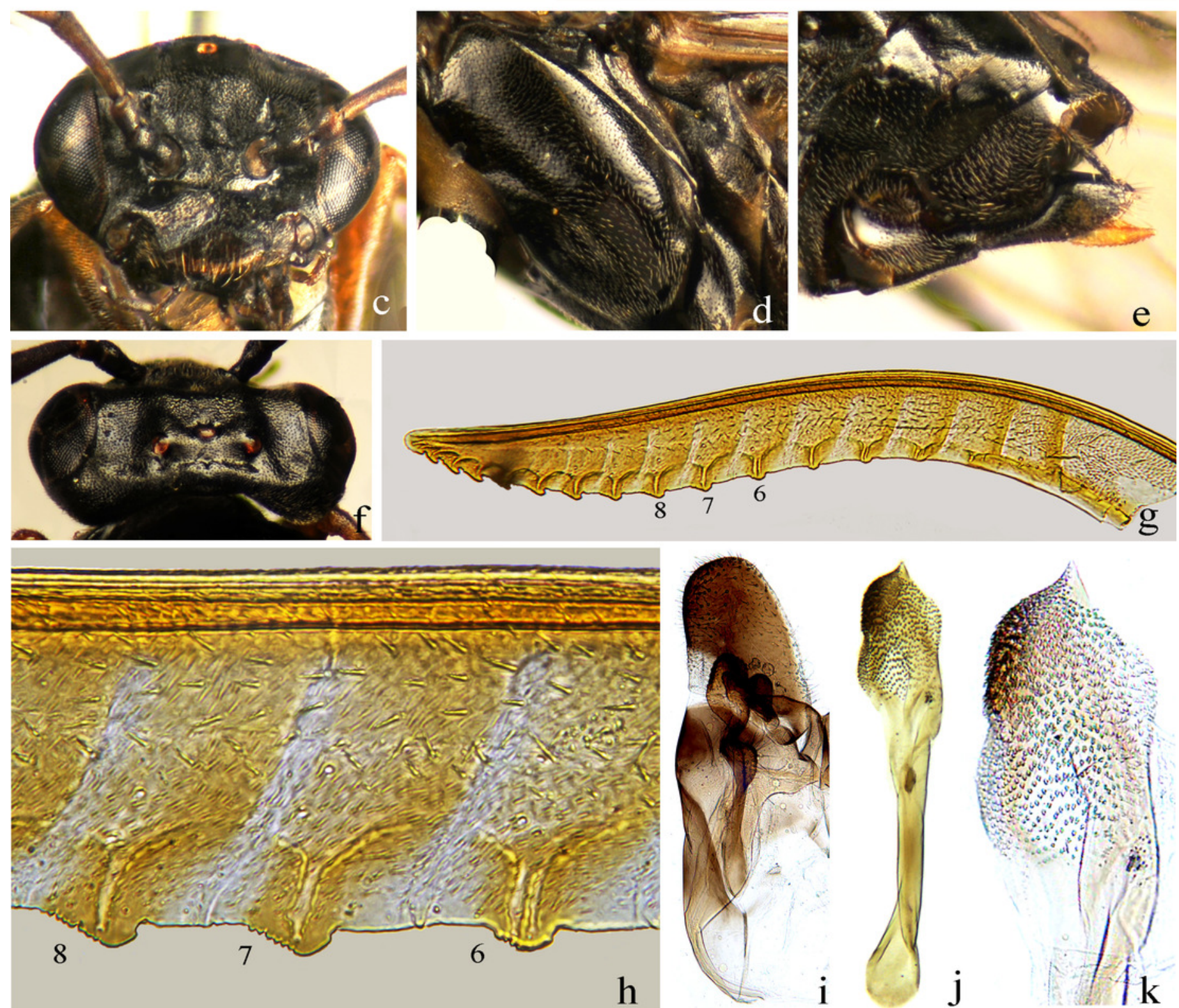

h
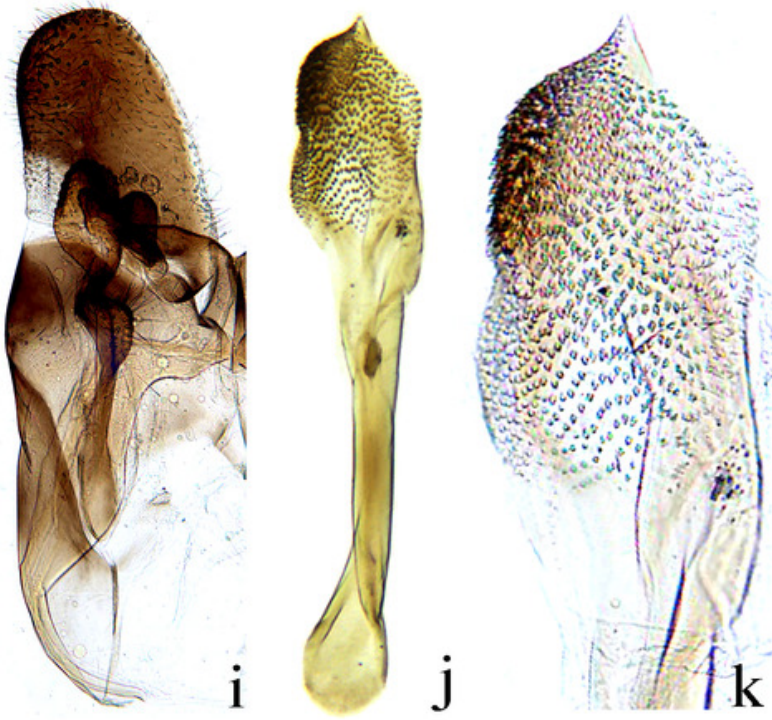
Figure 4

Analcellicampa danfengensis (Xiao). Female

a. Forewing; b. Hindwing; c. Maxilla; d. Labrum; e. Inner fore tibial spur; f. Claw; g. Left mandible; h. Right mandible; i. Antenna; j. Fore tibia and tarsus. Photos: Meicai Wei.

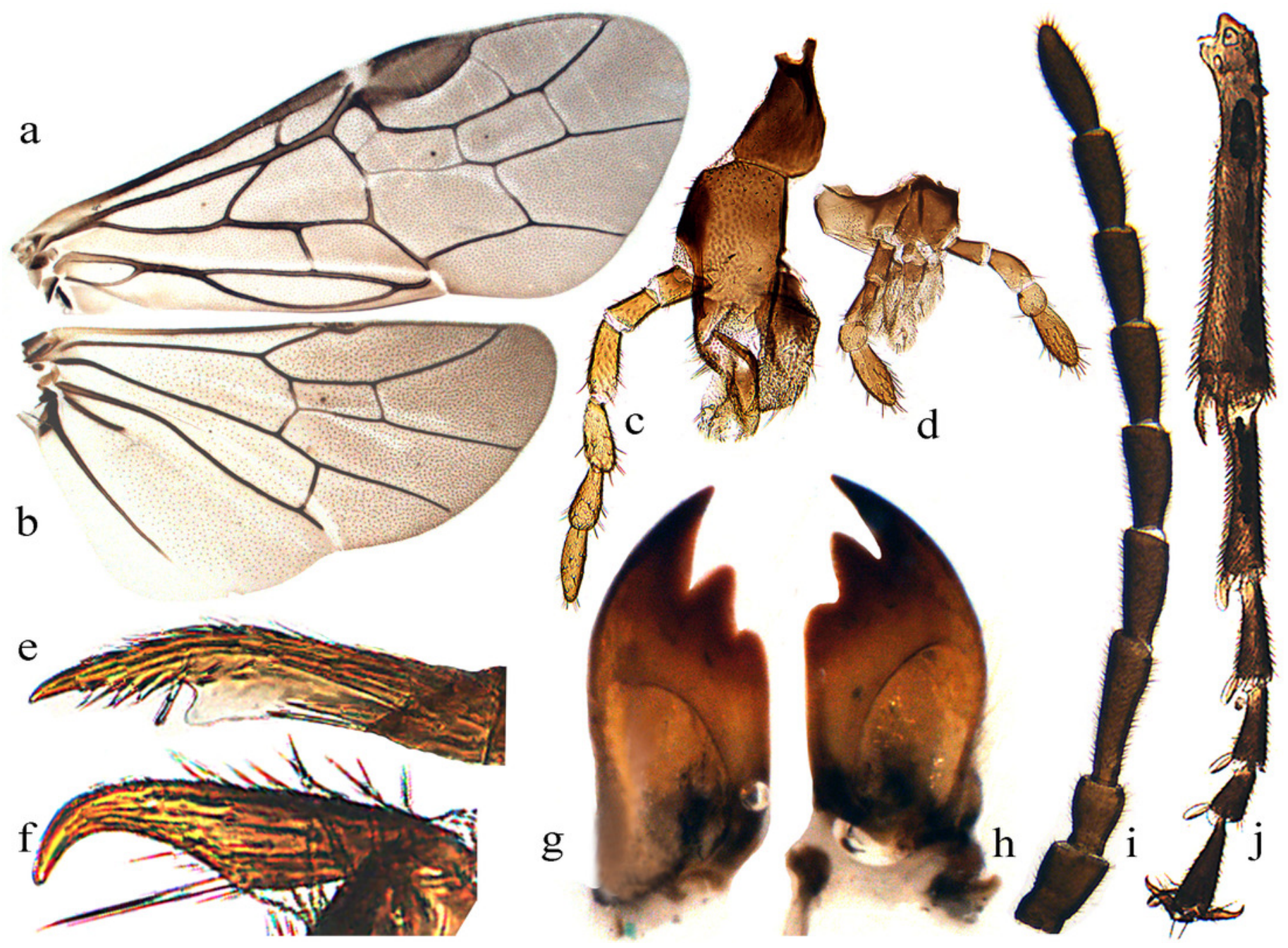




\section{Figure 5}

Mitochondrial genome organization of Analcellicampa xanthosoma.

Mitochondrial genome organization of $A$. xanthosoma with reference to the ancestral type of insect mitochondrial genomes. Genes transcribed from the J-and N-strands are shown in green and orange, respectively. Overlapping and intergenic regions are indicated by yellow and blue circles, respectively. The A+ T-rich region is indicated by blue, and tRNA genes are labeled by their single-letter amino acid code.

\section{Ancestral type}

a 1

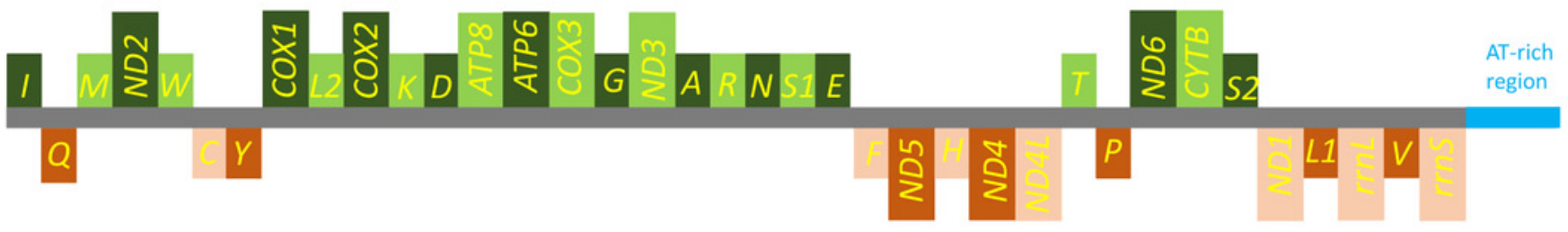

Analcellicampa xanthosoma

b
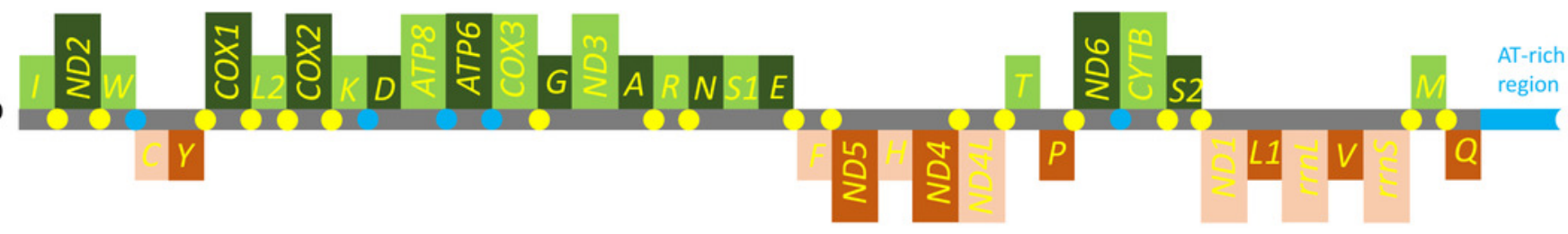
Figure 6

Predicted secondary structures of 22 tRNA genes of $A$. xanthosoma

Dashes indicate Watson-Crick base pairs, and dots indicate G-U base pairing. 


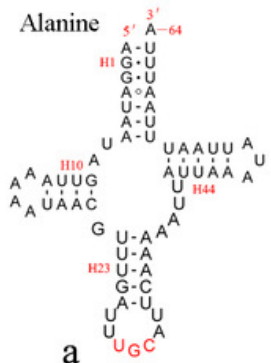

Glutamine

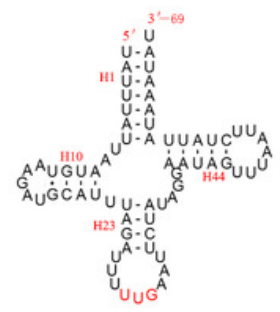

f

Leucine

(L1,CUN)

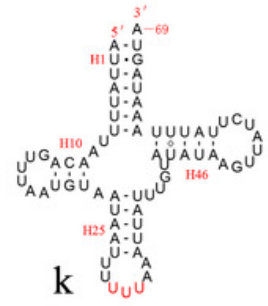

Proline

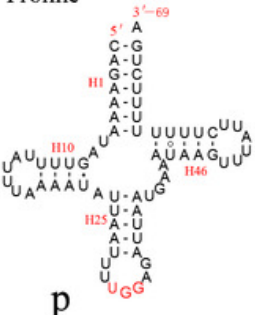

$\mathrm{p}$

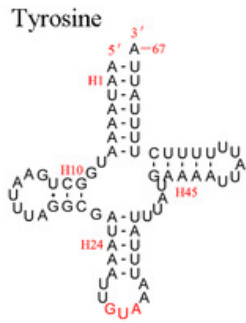

$\mathrm{u}$

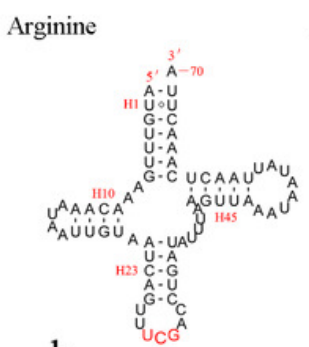

b

Glutamic acid

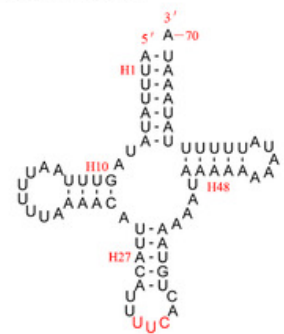

g

\begin{abstract}
Leucine
\end{abstract}
(L2,UUR)

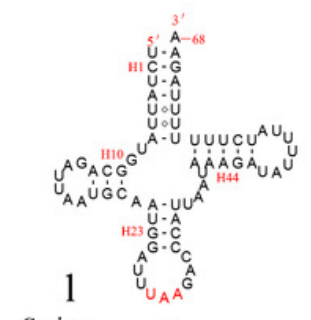

Serine

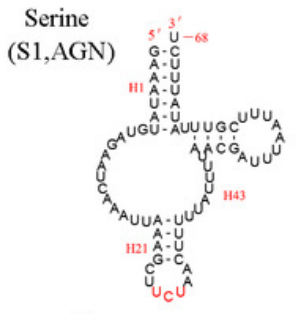

q

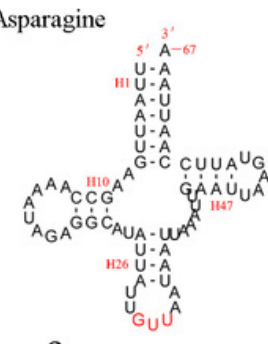

c

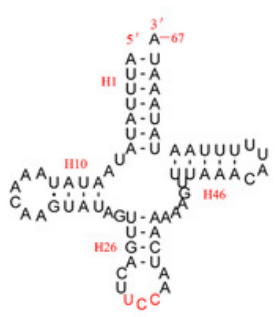

$\mathrm{h}$

Lysine

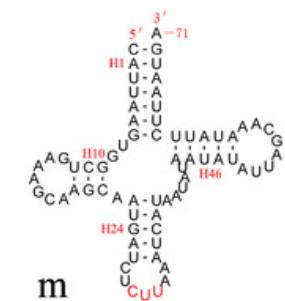

Serine

(S2,UCN)

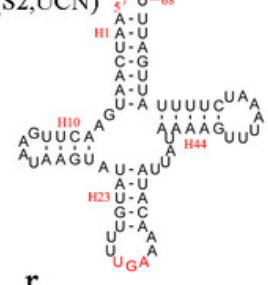

$\mathrm{r}$

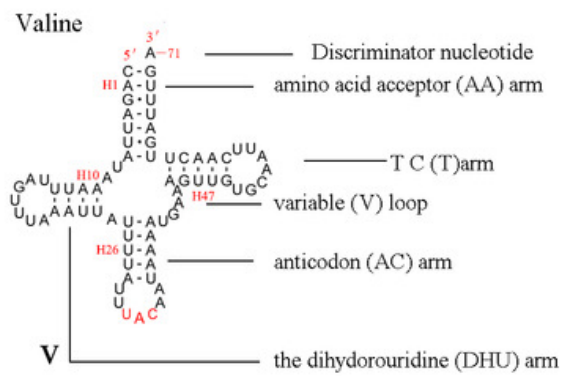

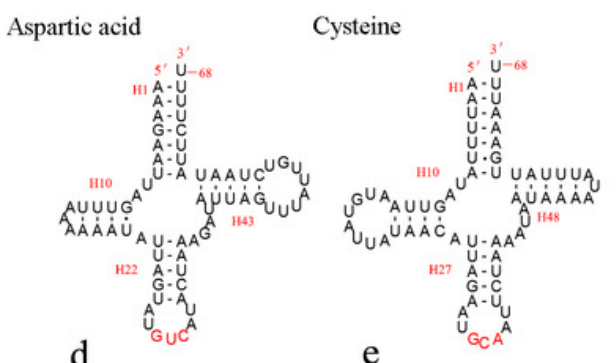

Histidine

Isoleucine

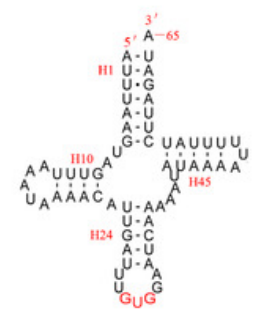

i

Methionine

Phenylalanine

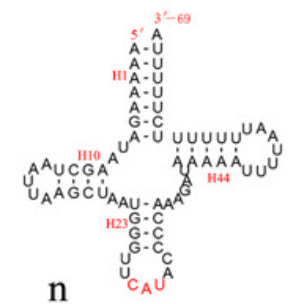

Threonine

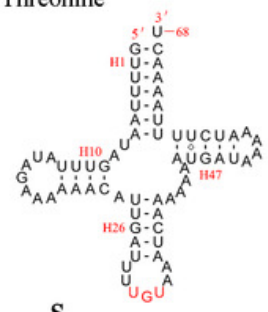

S

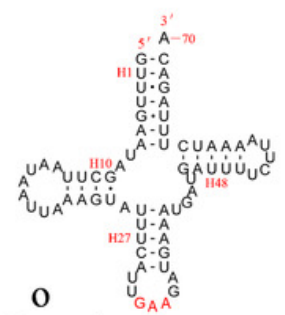

Tryptophan

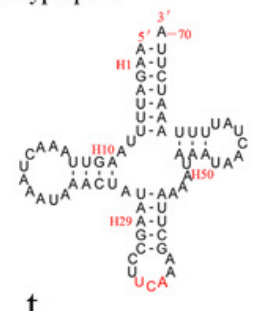

$\mathrm{t}$

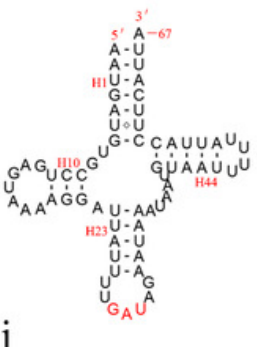


Figure 7

Predicted $r r n L$ secondary structure in the $A$. xanthosoma mitochondrial genome.

The numbering of helices follows Gillespie et al. (2006). Roman numerals refer to domain names.

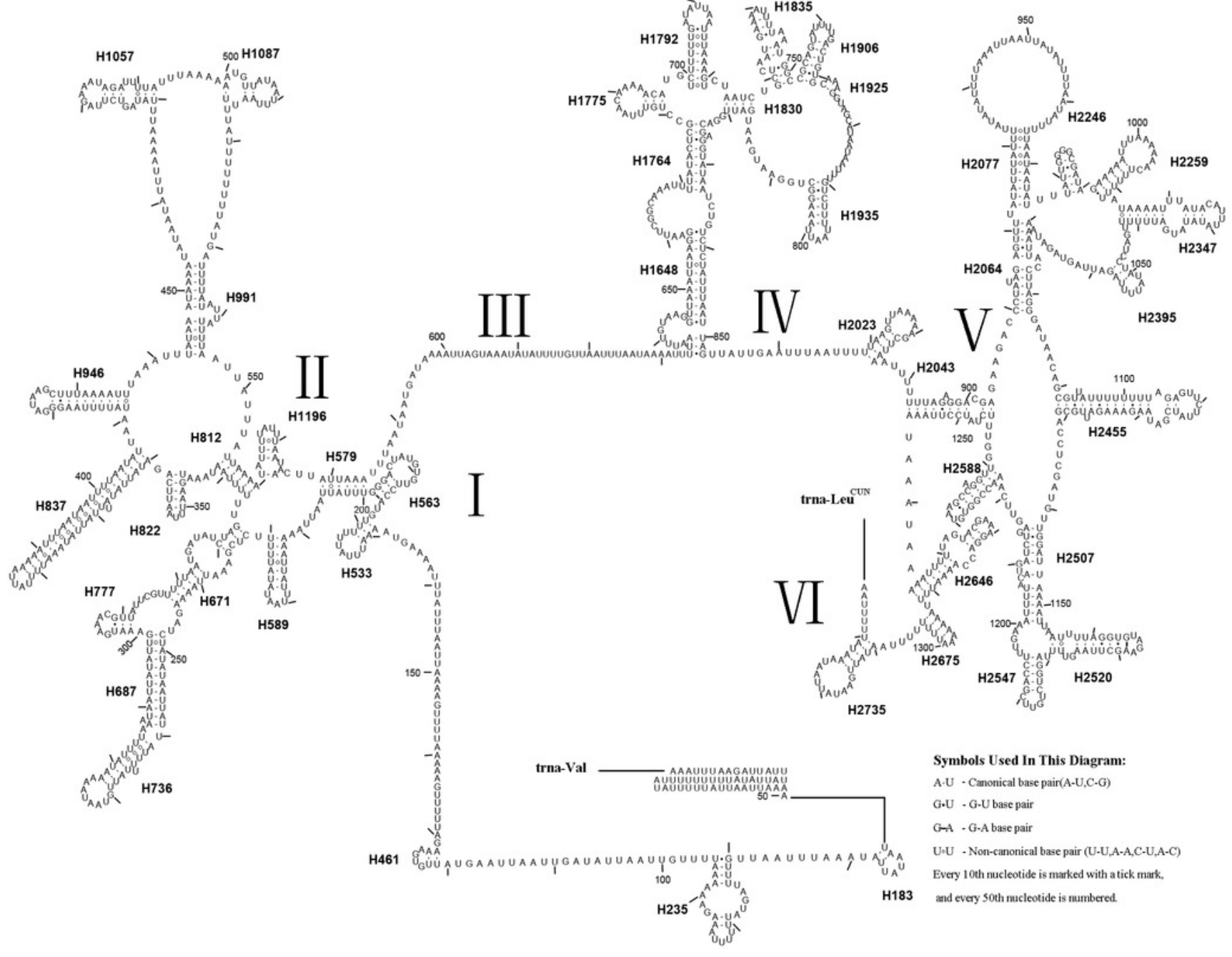




\section{Figure 8}

Predicted rrnS secondary structure in the A. xanthosoma mitochondrial genome.

The numbering of helices follows Gillespie et al. (2006). Roman numerals refer to domain names.

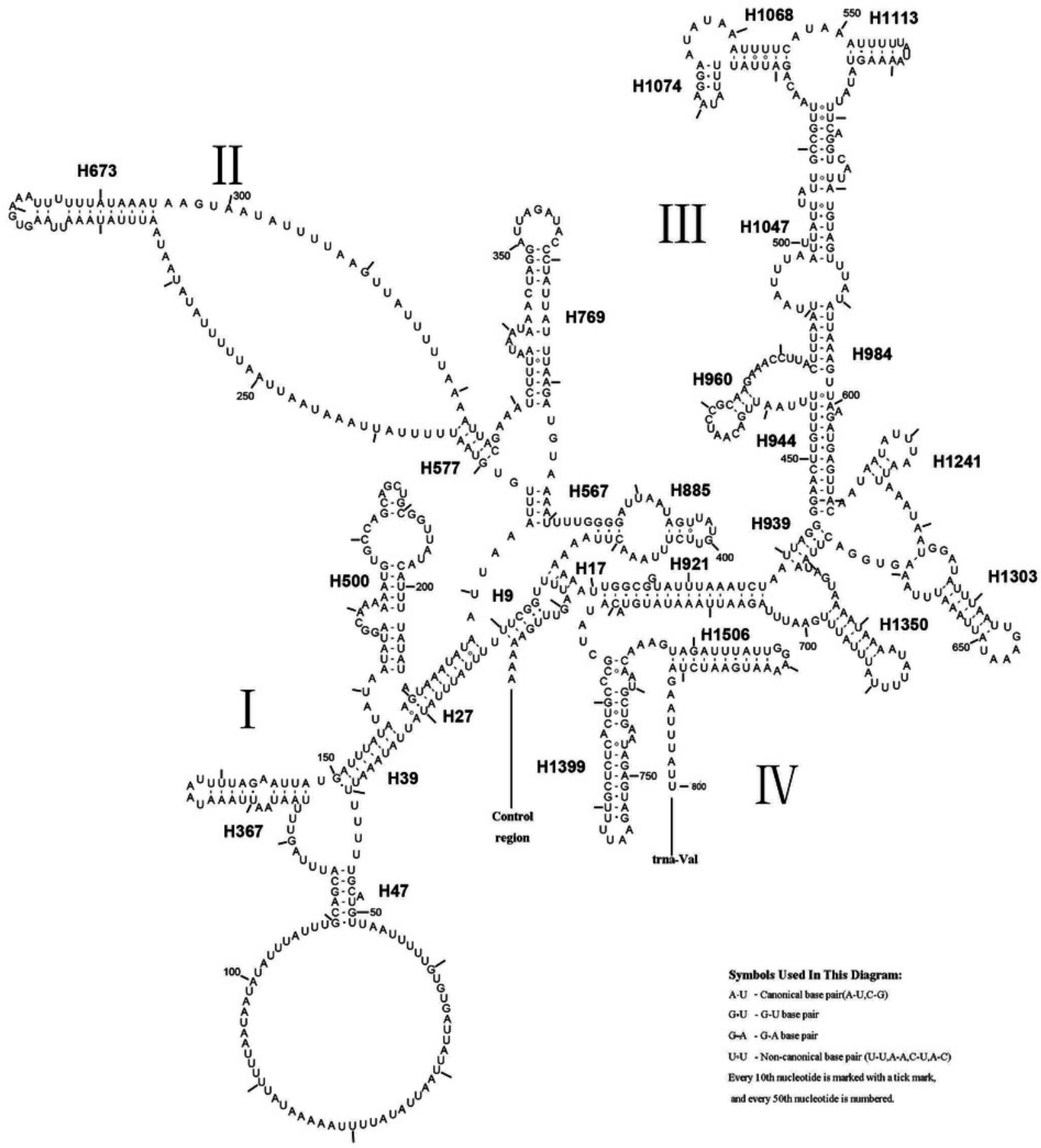


Figure 9

Symphytan phylogenetic tree constructed with BI and ML approaches using a mitogenome dataset including 15 individual genes (13 PCGs and two rRNAs).

Both analyses produced the same tree topology. Support values lower than $100 \%$ in the ML analysis and 1.0 in the $\mathrm{BI}$ analysis were shown.

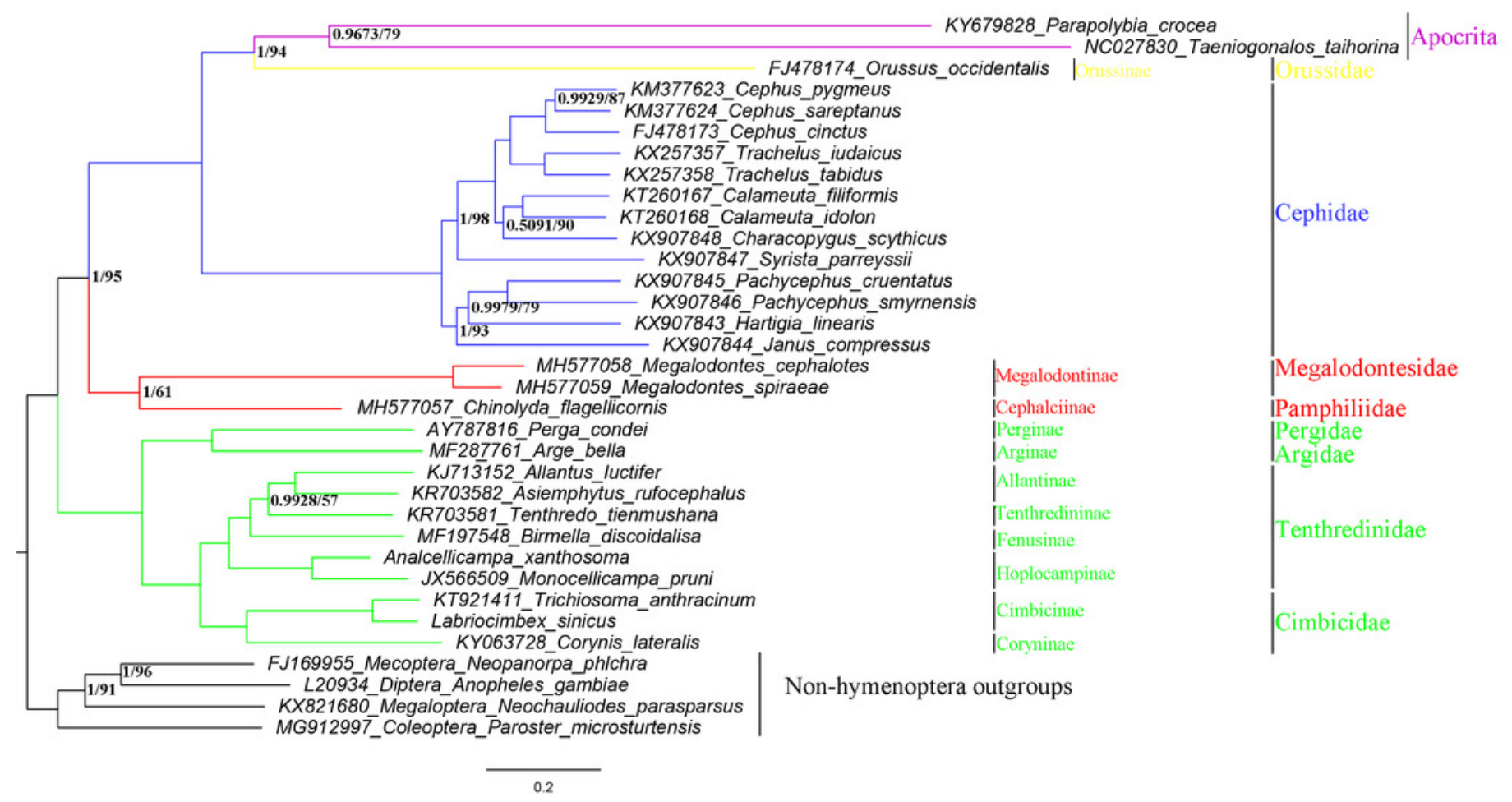




\section{Table 1 (on next page)}

Summary information of symphytan mitogenomes used in phylogenetic analyses. 
1 Summary information of symphytan mitochondrial genomes used in phylogenetic 2 analyses

\begin{tabular}{|c|c|c|c|c|}
\hline & Species & Family & $\begin{array}{l}\text { Accesion } \\
\text { number }\end{array}$ & References \\
\hline \multirow[t]{30}{*}{ Ingroup } & Analcellicampa xanthosoma & Tenthredinidae & & This study \\
\hline & Chinolyda flagellicornis & Pamphiliidae & MH577057 & Niu et al., 2019 \\
\hline & Megalodontes cephalotes & Megalodontesidae & MH577058 & Niu et al., 2019 \\
\hline & Megalodontes spiraeae & Megalodontesidae & MH577059 & Niu et al., 2019 \\
\hline & Allantus luctifer & Tenthredinidae & KJ713152 & Wei et al., 2014 \\
\hline & Arge bella & Argidae & MF287761 & Du et al., 2018 \\
\hline & Asiemphytus rufocephalus & Tenthredinidae & KR703582 & Song et al., 2016 \\
\hline & Calameuta filiformis & Cephidae & KT260167 & Korkmaz et al., 2016 \\
\hline & Calameuta idolon & Cephidae & KT2601678 & Korkmaz et al., 2016 \\
\hline & Cephus cinctus & Cephidae & FJ478173 & Dowton et al., 2009 \\
\hline & Cephus pygmeus & Cephidae & KM377623 & Korkmaz et al., 2015 \\
\hline & Cephus sareptanus & Cephidae & KM377624 & Korkmaz et al., 2015 \\
\hline & Characopygus scythicus & Cephidae & KX907848 & Korkmaz et al., 2018 \\
\hline & Labriocimbex sinicus & Cimbicidae & & Unpublished \\
\hline & Corynis lateralis & Cimbicidae & KY063728 & Doğan and Korkmaz, 2017 \\
\hline & Hartigia linearis & Cephidae & KX907843 & Korkmaz et al., 2018 \\
\hline & Janus compressus & Cephidae & KX907844 & Korkmaz et al., 2018 \\
\hline & Monocellicampa pruni & Tenthredinidae & JX566509 & Wei et al., 2015 \\
\hline & Birmella_discoidalisa & Tenthredinidae & MF197548 & Unpublished \\
\hline & Orussus occidentalis & Orussidae & FJ478174 & Dowton et al., 2009 \\
\hline & Pachycephus cruentatus & Cephidae & KX907845 & Korkmaz et al., 2018 \\
\hline & Pachycephus smyrnensis & Cephidae & KX907846 & Korkmaz et al., 2018 \\
\hline & Perga condei & Pergidae & AY787816 & Castro and Dowton, 2005 \\
\hline & Syrista parreyssi & Cephidae & KX907847 & Korkmaz et al., 2018 \\
\hline & Tenthredo tienmushana & Tenthredinidae & KR703581 & Song et al., 2015 \\
\hline & Trachelus iudaicus & Cephidae & KX257357 & Korkmaz et al., 2017 \\
\hline & Trachelus tabidus & Cephidae & KX257358 & Korkmaz et al., 2017 \\
\hline & Trichiosoma anthracinum & Cimbicidae & KT921411 & Song et al., 2016 \\
\hline & Taeniogonalos taihorina & Trigonalidae & $\mathrm{NC} 027830$ & Wu et al.,2014 \\
\hline & Parapolybia crocea & Vespidae & KY679828 & Peng et al.,2017 \\
\hline \multirow[t]{4}{*}{ Outgroup } & Paroster microsturtensis & Dytiscidae & MG912997 & Hyde et al.,2018 \\
\hline & Neopanorpa phlchra & Panorpidae & FJ169955 & Unpublished \\
\hline & Neochauliodes parasparsus & Corydalidae & KX821680 & Zhao et al.,2017 \\
\hline & Anopheles gambiae & Culicidae & L20934 & Beard et al.,1993 \\
\hline
\end{tabular}




\section{Table 2 (on next page)}

Mitochondrial genome characteristics of Analcellicampa xanthosoma.

J, major; N, minor; IGN, intergenic nucleotides. Minus indicates overlapping sequences between adjacent genes. 
Mitochondrial genome characteristics of Analcellicampa xanthosoma

\begin{tabular}{|c|c|c|c|c|c|c|c|}
\hline Gene & Strand & Start & Stop & Length(bp) & Start codon & Stop codon & IGN \\
\hline $\operatorname{trnI}$ & $\mathrm{J}$ & 1 & 67 & 67 & & & 5 \\
\hline$N D 2$ & $\mathrm{~J}$ & 73 & 1,119 & 1,047 & ATG & TAA & 6 \\
\hline $\operatorname{trn} W$ & $\mathrm{~J}$ & 1,126 & 1,195 & 70 & & & -1 \\
\hline $\operatorname{trnC}$ & $\mathrm{N}$ & 1,195 & 1,262 & 68 & & & 0 \\
\hline $\operatorname{trn} Y$ & $\mathrm{~N}$ & 1,263 & 1,329 & 67 & & & 9 \\
\hline COXI & $\mathrm{J}$ & 1,339 & 2,877 & 1,539 & ATA & TAA & 29 \\
\hline $\operatorname{trnL2}$ & $\mathrm{J}$ & 2,907 & 2,974 & 68 & & & 1 \\
\hline COX2 & $\mathrm{J}$ & 2,976 & 3,656 & 681 & ATG & TAA & 29 \\
\hline $\operatorname{trn} K$ & $\mathrm{~J}$ & 3,686 & 3,756 & 71 & & & -1 \\
\hline $\operatorname{trn} D$ & $\mathrm{~J}$ & 3,756 & 3,823 & 68 & & & 0 \\
\hline ATP8 & $\mathrm{J}$ & 3,824 & 3,982 & 159 & ATC & TAA & -7 \\
\hline ATP6 & $\mathrm{J}$ & 3,976 & 4,653 & 678 & ATG & TAA & -1 \\
\hline COX3 & $\mathrm{J}$ & 4,653 & 5,441 & 789 & ATG & TAA & 11 \\
\hline $\operatorname{trn} G$ & $\mathrm{~J}$ & 5,453 & 5,519 & 67 & & & 0 \\
\hline$N D 3$ & $\mathrm{~J}$ & 5,520 & 5,871 & 352 & ATT & $\mathrm{T}$ & 0 \\
\hline $\operatorname{trn} A$ & $\mathrm{~J}$ & 5,872 & 5,935 & 64 & & & 14 \\
\hline $\operatorname{trnR}$ & $\mathrm{J}$ & 5,950 & 6,019 & 70 & & & 2 \\
\hline $\operatorname{trnN}$ & $\mathrm{J}$ & 6,022 & 6,088 & 67 & & & 0 \\
\hline $\operatorname{trnS1}$ & $\mathrm{J}$ & 6,089 & 6,156 & 68 & & & 0 \\
\hline $\operatorname{trnE}$ & $\mathrm{J}$ & 6,157 & 6,226 & 70 & & & 4 \\
\hline $\operatorname{trn} F$ & $\mathrm{~N}$ & 6,231 & 6,300 & 70 & & & 10 \\
\hline ND5 & $\mathrm{N}$ & 6,311 & 8,035 & 1,725 & ATT & TAA & 0 \\
\hline
\end{tabular}




$\begin{array}{lccccccc}\operatorname{trnH} & \mathrm{N} & 8,036 & 8,100 & 65 & & & 0 \\ N D 4 & \mathrm{~N} & 8,101 & 9,445 & 1,345 & \text { ATG } & \mathrm{T} & 4 \\ N D 4 L & \mathrm{~N} & 9,450 & 9,749 & 300 & \text { ATG } & \text { TAA } & 2 \\ \operatorname{trnT} & \mathrm{J} & 9,752 & 9,819 & 68 & & & 0 \\ \operatorname{trn} P & \mathrm{~N} & 9,820 & 9,888 & 69 & & & 5 \\ N D 6 & \mathrm{~J} & 9,894 & 10,409 & 516 & \text { ATG } & \text { TAA } & -1 \\ C Y T B & \mathrm{~J} & 10,409 & 11,545 & 1,137 & \text { ATG } & \text { TAA } & 5 \\ \operatorname{trnS2} & \mathrm{J} & 11,551 & 11,618 & 68 & & & 19 \\ N D 1 & \mathrm{~N} & 11,638 & 12,588 & 951 & \text { ATA } & \text { TAA } & 0 \\ \operatorname{trnL1} & \mathrm{N} & 12,589 & 12,657 & 69 & & & 0 \\ \operatorname{rrnL} & \mathrm{N} & 12,658 & 13,993 & 1,336 & & & 0 \\ \operatorname{trn} V & \mathrm{~N} & 13,994 & 14,064 & 71 & & & 0 \\ \operatorname{rrnS} & \mathrm{N} & 14,065 & 14,864 & 800 & & & 33 \\ \operatorname{trn} M & \mathrm{~J} & 14,898 & 14,966 & 69 & & & 51 \\ \operatorname{trn} Q & \mathrm{~N} & 15,018 & 15,086 & 69 & & & 0 \\ \text { AT-rich } & \mathrm{J} & 15,087 & >15,512 & >426 & & & \\ \operatorname{region} & & & & & & \end{array}$




\section{Table 3(on next page)}

Nucleotide composition of Analcellicampa xanthosoma mitochondrial genome. 
Nucleotide composition of Analcellicampa xanthosoma mitochondrial genome

\begin{tabular}{|c|c|c|c|c|c|c|c|c|}
\hline Feature & Length(bp) & $\mathbf{A} \%$ & $\mathrm{C} \%$ & G\% & T\% & $\mathrm{A}+\mathrm{T} \%$ & AT-skew & GC-skew \\
\hline Protein coding genes & 11180 & 34.6 & 10.7 & 10.3 & 44.4 & 79.0 & -0.1241 & -0.0190 \\
\hline First codon position & 3727 & 34.9 & 10.2 & 12.2 & 43.0 & 77.9 & -0.1040 & 0.0893 \\
\hline Second codon position & 3727 & 30.6 & 12.5 & 10.5 & 46.0 & 76.6 & -0.2010 & -0.0870 \\
\hline Third codon position & 3726 & 38.2 & 9.4 & 8.3 & 44.0 & 82.2 & -0.0706 & -0.0621 \\
\hline First codon position & 2291 & 40.3 & 11.3 & 12.3 & 36.0 & 76.3 & 0.0564 & 0.0424 \\
\hline Second codon position & 2290 & 26.0 & 18.3 & 12.5 & 43.0 & 69.0 & -0.2464 & -0.1883 \\
\hline Third codon position & 2290 & 44.2 & 9.2 & 3.4 & 43.0 & 87.2 & 0.0138 & -0.4603 \\
\hline Protein coding genes- $\mathrm{N}$ & 4309 & 31.0 & 7.1 & 11.9 & 50.0 & 81.0 & -0.2346 & 0.2526 \\
\hline First codon position & 1437 & 34.7 & 5.1 & 12.3 & 48.0 & 82.7 & -0.1608 & 0.4138 \\
\hline ATP8 & 159 & 42.1 & 8.2 & 2.5 & 47.2 & 89.3 & -0.0571 & -0.5327 \\
\hline$C O X 1$ & 1539 & 33.3 & 14.6 & 12.7 & 39.4 & 72.7 & -0.0839 & -0.0696 \\
\hline COX2 & 681 & 40.4 & 12.8 & 9.3 & 37.6 & 78.0 & 0.0359 & -0.1584 \\
\hline COX3 & 789 & 34.0 & 15.6 & 11.9 & 38.5 & 72.5 & -0.0621 & -0.1345 \\
\hline CYTB & 1137 & 33.9 & 14.1 & 10.9 & 41.1 & 75.0 & -0.0960 & -0.1280 \\
\hline$N D 1$ & 951 & 49.1 & 12.8 & 8.4 & 29.7 & 78.8 & 0.2462 & -0.2075 \\
\hline$N D 2$ & 1047 & 42.7 & 9.6 & 4.9 & 42.8 & 85.5 & -0.0012 & -0.3241 \\
\hline$N D 3$ & 352 & 36.1 & 11.4 & 8.5 & 44.0 & 80.1 & -0.0986 & -0.1457 \\
\hline ND4 & 1345 & 50.3 & 12.1 & 7.0 & 30.6 & 80.9 & 0.2435 & -0.2670 \\
\hline
\end{tabular}




\begin{tabular}{lcccccccc}
$N D 4 L$ & 300 & 53.3 & 13.3 & 1.7 & 31.7 & 85.0 & 0.2541 & -0.7733 \\
$N D 5$ & 1725 & 49.7 & 10.9 & 7.5 & 31.9 & 81.6 & 0.2181 & -0.1848 \\
$N D 6$ & 516 & 41.5 & 10.3 & 5.4 & 42.8 & 84.3 & -0.0154 & -0.3121 \\
$r r n L$ & 1336 & 45.4 & 10.9 & 5.7 & 38.0 & 83.4 & 0.0887 & -0.3133 \\
$r r n S$ & 800 & 43.6 & 11.5 & 6.1 & 38.8 & 82.4 & 0.0583 & -0.3068 \\
\hline
\end{tabular}




\section{Table 4 (on next page)}

Codon usage of 13 PCGs in mitochondrial genome of Analcellicampa xanthosoma.

No, frequency of each codon; RSCU, relative synonymous codon usage. 
Codon usage of PCGs in mitochondrial genome of Analcellicampa xanthosoma

\begin{tabular}{|c|c|c|c|c|c|c|c|}
\hline Amino acid & Codon & NO. & RSCU & Amino acid & Codon & NO. & RSCU \\
\hline \multirow[t]{2}{*}{ Phe } & UUU & 407 & 1.66 & Tyr & UAU & 200 & 1.69 \\
\hline & UUC & 82 & 0.34 & & UAC & 37 & 0.31 \\
\hline \multirow[t]{2}{*}{ Leu } & UUA & 308 & 3.84 & End & UAA & 129 & 1.39 \\
\hline & UUG & 43 & 0.54 & & UAG & 57 & 0.61 \\
\hline \multirow[t]{4}{*}{ Leu } & CUU & 55 & 0.69 & His & CAU & 64 & 1.62 \\
\hline & CUC & 9 & 0.11 & & CAC & 15 & 0.38 \\
\hline & CUA & 53 & 0.66 & Gln & CAA & 58 & 1.81 \\
\hline & CUG & 13 & 0.16 & & CAG & 6 & 0.19 \\
\hline \multirow[t]{2}{*}{ Ile } & AUU & 352 & 1.73 & Asn & AAU & 227 & 1.77 \\
\hline & AUC & 55 & 0.27 & & AAC & 30 & 0.23 \\
\hline \multirow[t]{2}{*}{ Met } & AUA & 197 & 1.66 & Lys & AAA & 126 & 1.58 \\
\hline & AUG & 40 & 0.34 & & AAG & 33 & 0.42 \\
\hline \multirow[t]{4}{*}{ Val } & GUU & 38 & 1.33 & Asp & GAU & 67 & 1.72 \\
\hline & GUC & 12 & 0.42 & & GAC & 11 & 0.28 \\
\hline & GUA & 53 & 1.86 & Glu & GAA & 60 & 1.48 \\
\hline & GUG & 11 & 0.39 & & GAG & 21 & 0.52 \\
\hline \multirow[t]{4}{*}{ Ser } & UCU & 55 & 1.48 & Cys & UGU & 24 & 1.17 \\
\hline & UCC & 24 & 0.65 & & UGC & 17 & 0.83 \\
\hline & $\mathrm{UCA}$ & 102 & 2.75 & $\operatorname{Trp}$ & UGA & 73 & 1.47 \\
\hline & UCG & 8 & 0.22 & & UGG & 26 & 0.53 \\
\hline \multirow[t]{2}{*}{ Pro } & $\mathrm{CCU}$ & 31 & 1.51 & $\operatorname{Arg}$ & CGU & 4 & 0.67 \\
\hline & $\mathrm{CCC}$ & 14 & 0.68 & & CGC & 1 & 0.17 \\
\hline
\end{tabular}




\begin{tabular}{cccccccc}
\multirow{4}{*}{ Thr } & CCA & 36 & 1.76 & & CGA & 17 & 2.83 \\
& CCG & 1 & 0.05 & Ser & CGG & 2 & 0.33 \\
& ACU & 52 & 1.58 & & AGU & 21 & 0.57 \\
& ACC & 15 & 0.45 & & AGC & 13 & 0.35 \\
\multirow{4}{*}{ Ala } & ACA & 61 & 1.85 & & AGA & 46 & 1.24 \\
& ACG & 4 & 0.12 & & AGG & 28 & 0.75 \\
& GCU & 24 & 1.50 & Gly & GGU & 20 & 0.68 \\
& GCC & 8 & 0.50 & & GGC & 7 & 0.24 \\
& GCA & 31 & 1.94 & & GGA & 74 & 2.51 \\
& GCG & 1 & 0.06 & & GGG & 17 & 0.58 \\
\hline
\end{tabular}

